\title{
CAHLE PENTRU CORONAMENTUL SOBELOR MEDIEVALE DIN TARA ROMÂNEASCĂ (SECOLELE XIV-XVII)
}

\author{
MARIA-VENERA RĂDULESCU
}

\author{
TILES FOR MEDIEVAL STOVE CANOPY IN WALLACHIA \\ $\left(14^{\mathrm{TII}}-17^{\mathrm{TII}}\right.$ CENTURIES)
}

\begin{abstract}
Considering the excavation technique and the shapes, the stove canopy in Wallachia can be categorized as follows: disc tiles, convex tiles, tiles with simple fixing frame (spangle), fretwork tiles with niche type fixing frame, plate tiles. The pieces have constructive particularities, pertaining to the functionality for which they were made. The decorative repertory of the tiles comprises different motifs: architectural, stylized-anthropomorphic figures, geometric, floral ornaments, etc.
\end{abstract}

KEYWORDS: disc tiles, convex tiles, tiles with fretwork patterns, panel tiles

CUVINTE CHEIE: cahle-disc, cahle-convexe, cahle-traforate, cahle-placă

Soba de cahle, ca instalaţie de încălzit specifică regiunilor central și est europene, cunoaşte în Evul Mediu o evoluţie continuă a structurii sale arhitecturale şi a valorii artistice a teracotelor ce o împodobesc. Veridice documente istorice, cahlele abordează un repertoriu ornamental divers, de la reprezentări de oşteni înarmaţi, în echipamentul militar al epocii, la scene de turnir, teme religioase, portrete - uneori de suverani -, motive heraldice, florale, arhitecturale, geometrice, animaliere ş.a. Concepută ca o volumetrie ce transferă în spaţiul interior elemente ale construcţiilor laice sau ecleziastice, miniaturizate şi sintetizate, soba, prin structură şi elemente decorative, poartă amprenta caracteristicilor arhitecturii epocii. Cele mai relevante sunt cahlele de coronament, ele imprimând sobei o trimitere fie la catedrale, fie la turnuri şi curtine de cetăți, cu ambrazuri. Din punct de vedere al tehnicii de execuţie şi al formelor, cahlele de coronament din Tara Românească pot fi grupate în: cahle-disc, cahle-convexe, cahle-traforate cu corp de fixare simplu (lamelă), cahle-traforate cu corp de fixare de tip nişă, cahle-placă. Piesele prezintă particularităţi constructive raportate la funcţionalitatea pentru care au fost create. Funcţia acestor cahle este doar decorativă. Ornamentica poartă amprenta stilistică a epocii.

\section{CAHLE-DISC, PENTRU CORONAMENT}

Sub influenţa sud-dunăreană, cu o largă răspândire la monumentele bizantine din Bulgaria şi Serbia, decorul în forma unor discuri cu picior (ciupercuţe) sau flori cruciforme, din ceramică smălţuită, a fost iniţial folosit, încă din secolul al XIII-lea şi, apoi, în următoarele două secole, la ornamentarea pereţilor exteriori ai unor locaşe de cult ortodoxe din Muntenia şi Moldova. Ne referim la cele două biserici de la Turnu Severin (jud. Mehedinți), la biserica mănăstirii Vodiţa' (com. Vârciorova, jud. Mehedinți), la biserica I de la Argeş ${ }^{2}$ (Curtea de Argeş, jud. Argeș), la paraclisul Curţii Domneşti din Târgovişte ${ }^{3}$ (jud. Dâmbovița), monumente acum în ruină, şi la bisericile, în funç̧iune până astăzi, de la Cozia ${ }^{4}$ (jud. Vâlcea), Cotmeana ${ }^{5}$ (jud. Argeș), biserica Sfânta Vineri din

\footnotetext{
${ }^{1}$ Slătineanu 1958,68

${ }^{2}$ Constantinescu 1984, 141, fig. 68

${ }^{3}$ Moisescu 1979, 118

${ }^{4}$ Scurtã istorie 1957, 50; Theodorescu 1976, fig. 219, 225

${ }^{5}$ Scurtă istorie 1957, 51, fig. 45; Theodorescu 1976, fig. 214-217
} 
incinta Curţii Domneşti din Târgovişte ${ }^{6}$, iar în Moldova, la biserica Sfânta Treime din Siret (jud. Suceava) sau la ctitoriile lui Ştefan cel Mare ${ }^{7}$.

Pe teritoriului de la sud de Munţii Carpaţi, discul ceramic, smălţuit sau nesmălţuit, primind ornamente concentrice, va fi utilizat şi la decorarea instalaţiilor de încălzit ${ }^{8}$. Cele mai timpurii cahledisc, databilc în a doua jumătate a secolului al XIV-lea (circa 1370), au fost descoperite în timpul cercetărilor arheologice de la Curtea de Argeş, piese destinate a decora sobele din reşedinţa voievodalăa , dar şi pe cele din locuinţele orăşeneşti ${ }^{10}$. Cahlele-disc puteau fi folosite în arhitectura sobei, atât la decorarea camerei de ardere sau a celei de încălzire, alternând cu alte tipuri de piese, cât şi la decorarea coronamentului. La Târgovişte, cercetarea arheologică a unei locuinţe medievale (L 1 B), care a funcţionat la sfârşitul secolului al XIV-lea (1380-1390), a scos la lumină componentele unei instalaţii de gătit-încălzit, o sobă ce se înscrie prin concept sobelor romanico-gotice ${ }^{11}$ (PI. I/1). Unele dintre cele 15 exemplare de cahle-disc descoperite erau folosite la decorarea coronamentului. În funcţie de decor şi dimensiuni (diam. între 13-15,5 cm), piesele înscriu patru variante; toate prezintă un buton central lăţit şi albiat, smălţuit, culoare verde-oliv, iar câteva au ca omament cercuri concentrice în relief. Cahlele-disc care decorau partea superioară a sobei aveau modelat, din lut, un vârf terminal, un element ormamental, triunghiular, în forma unei „picături ${ }^{12 ”}$ (Pl. I/2). Meşterul târgoviştean ajunge la această soluţie preluând unele omamente caracteristice sobei gotice central europene, pe care le descompune şi apoi le recompune cu mijloace proprii, în încercarea de a realiza efecte plastice asemănătoare ${ }^{13}$. Tot la Târgovişte, cercetarea arheologică din anul $1984^{14}$, a locuinţei B 2, databilă la începutul secolului al XV-lea, a scos la lumină, printre alte teracote ce alcătuiseră instalaţia de încălzit, un fragment ceramic, în formă de bulb (h: $6,5 \mathrm{~cm})$, parţial smălţuit, culoare verde, parte componentă a unei cahle-disc de coronament (Pl. I/5). Astfel de teracote erau folosite în secolul al XV-lea şi la decorarea coronamentului sobelor de la Târgşor (Târgşoru Vechi, jud. Prahova), oraş medieval cu o prosperă via̧̧ă economică. Pe circumferinţă, în partea superioară a discurilor, era redată o procminenţă decorativă, uneori sferică, alteori conică (PI. I/3-4; VII/2). Piesele nu sunt smălţuite.

\section{CAHLE-CONVEXE, PENTRU CORONAMENT}

În decorarea coronamentului sobelor, un loc special îl ocupă cahlele-convexe. Corpul acestor piese este cilindric, cu partea superioară în forma unui bulb. În secolul al XIV-lea, în Europa centrală, cahlele-convexe erau utilizate în mod frecvent la construirea unor sobe ${ }^{15}$. S-au sugerat diferite soluţii de reconstituire grafică a formei iniţiale a instalaţiilor de încălzit ce foloseau asemenea teracote ${ }^{16}$.

În Tara Românească cunoaştem două exemplare din această tipologie: unul descoperit la Mânăstirea Snagov (jud. Ilfov), iar celălalt la Târgovişte. Piesa de la Snagov, a fost prezentată de autorul descoperirii drept „un obiect de lut" ce făcea parte din lotul de cahle descoperit în aproprierea zidurilor altarului ${ }^{17}$. Necunoscându-i-se utilizarea, desenul este publicat răsturnat ${ }^{18}$. Cahla, de formă tubulară (h: $18 \mathrm{~cm}$ ), are plasat în vârful bulbului un mic ornament, înalt de $2 \mathrm{~cm}$, în forma unui ,boboc de floare" (PI. II/1). Încadrată cronologic la sfârşitul secolului al XIV-lea sau în primele decenii ale

\footnotetext{
${ }^{6}$ Moisescu 1979, 124-125, fig. 179

${ }^{7}$ Nicolescu 1961, 373-394; Nicolescu 1964, 259-362

8 În Moldova și Transilvania nu sunt semnalate cahle-disc. Pentru teritoriul Ungariei, vezi Kálmán 1938, 92, fig. $424,431$.

${ }^{9}$ Constantinescu 1984, 138, fig. 65/1

${ }^{10}$ Bătrâna, Bătrâna 1981 , 166, fig. 14/3

${ }^{11}$ Constantinescu, Ionescu 1980, p. 62-72, fig. 6

${ }^{12}$ Constantinescu, Ionescu 1980, fig. 9

${ }^{13}$ Constantinescu, Ionescu 1980, 66, fig. 9/1, fig. 11

${ }^{14}$ Diaconescu 1997, fig. $3 / 2$

${ }_{15}^{15}$ Бирташевиъ 1970, fig. 85, 86; Richterová 1982, fig. 1, 2

${ }^{16}$ Hoššo 1982, 499-508, fig. 5 (pentru descoperirile de la Liptovska Mara, Cehia); Boldizsár 1988, fig. 19 (pentru piesele de la Buda, Ungaria)

${ }^{17}$ Rosetti 1935, 20

${ }^{18}$ Rosetti 1935, fig. 35
} 
secolului următor, piesa ornamenta, probabil, o sobă instalată în prima biserică de la Snagov. La Târgovişte, o cahlă de coronament convexă a fost descoperită în ruinele unei locuinţe medievale (L 31) distruse de un incendiu, la sfârşitul secolului al XIV-lea ${ }^{19}$. Piesa are corpul tubular (h: $\left.19 \mathrm{~cm}\right)$, evazat în partea inferioară, unde rămâne deschis. Partea superioară are forma unui bulb, omamentat central cu un buton plat acoperit cu smalt, culoare verde. Interiorul corpului cilindric, ca şi marginile părţii inferioare, păstrează fragmente din lutul ce a servit la fixarea piesei la sobă (Pl. II/2; VII/1).

Cahlele-convexe pentru coronament îşi găsesc analogii, atât în piesele transilvănene, cât şi în cele moldoveneşti. Din Transilvania, menţionăm o cahlă descoperită la Arad $^{20}$ şi o alta la Bodrog ${ }^{21}$ (jud. Arad). În Moldova, cahle-convexe pentru coronament au fost folosite în secolele XIV-XV la sobele de la Baia ${ }^{22}$ (jud. Suceava), Bacău ${ }^{23}$ (jud. Bacău), Suceava ${ }^{24}$, Roman $^{25}$ (jud. Neamț), Mânăstirea Pătrăuţi ${ }^{26}$,Todireşti ${ }^{27}$ (jud. Suceava) ş.a. Acestea înscriu forme, dimensiuni şi decoruri variate. Asemănătoare pieselor descoperite în Valahia sunt cahlele-convexe descoperite la Bacău. În privinţa locului ce-l ocupau cahlele de aceste tipuri în algoritmul sobelor moldovenești, se presupune că la Baia ele erau utilizate, atât pentru decorarea coronamentului, cât și a registrelor de pe feţele sobei ${ }^{28}$.

\section{CAHLE-TRAFORATE, PENTRU CORONAMENT}

Acest tip de piese necesită o confecţionare mai elaborată. După imprimarea decorului în tipar, anumite zone ale ornamentului sunt decupate, operaţiune realizată cu instrumente speciale de lemn (spatule). Cahlele-traforate destinate coronamentului pot prezenta, ca sistem de montare la sobă, fie o lamelă simplă, amplasată pe latura lor inferioară, fie un corp lucrat la roata olarului şi ataşat pe revers (nişă). Corpul de fixare se adaptează la forma şi dimensiunile cahlei traforate, având de obicei aspectul unui sfert de cilindru, mai rar a unui semicilindru. Lateralele corpului de fixare sunt obturate cu plăcuţe de lut în forma unor segmente de cerc.

\section{III.A. CAHLE TRAFORATE CU SISTEM DE FIXARE SIMPLU (LAMELĂ)}

Latura inferioară a acestor teracote, lamela, se montează, cu lut, pe muchia superioară a sobei. Decorul poate fi inspirat din arhitectură, motive antropomorfe stilizate, geometrice, vegetale ş.a.

\section{III.A.a. DECOR INSPIRAT DIN ARHITECTURĂ}

Acest ornament este cel mai frecvent.

În Bucureşti, în zona Mănăstirii Radu Vodă, au fost descoperite fragmente de cahle de formă rectangulară, traforate, smălţuite, culoare verde, având ca decor arcade şi triunghiuri, încadrate de chenare din butoni şi nervuri în zig-zag ${ }^{29}$. Piesele sunt databile în prima jumătate a secolului al XVIlea. La Măicăneşti-Străuleşti, fost sat medieval, sunt descoperite fragmentele unor cahle de formă trapezoidală $(19 \times 14,5 \times 11,5 \mathrm{~cm})$, cu decor traforat, piese databile în secolele XV-XVI ${ }^{30}$. Registrul superior, plin, este decorat cu nervuri ce formează triunghiuri, iar în registrul inferior sunt redate două arcade, dintre care una traforată, sugerând o fereastră (Pl. III/3).

\footnotetext{
${ }^{19}$ Ionescu 1983, 70, fig. 8/a

${ }^{20}$ Marcu-Istrate 2004, 179, pl. 8 B/3

${ }^{21}$ Marcu-Istrate 2004, pl. 12 A 1

22 Neamţu, Neamţu, Cheptea 1980, 134-137, fig. 107/2-9; 114/11-13; 116/8-11; 117/10-11; Neamţu, Neamţu, Cheptea 1984, 237, 239, fig. 106/1-6; Batariuc 1997, 129, fig. 3/1, 5, fig. 4/1-5

${ }^{23}$ Batariuc 1997, 129, fig. 3/2, 3

${ }^{24}$ Batariuc 1997 , 128, fig. $3 / 6,7$, fig. $4 / 6$

${ }^{25}$ Batariuc 1997, 129

${ }^{26}$ Batariuc 1997, 129

${ }^{27}$ Batariuc 1997, fig. $3 / 4$

${ }^{28}$ Neamţ, Neamtu, Cheptea 1984, 237, 239, fig. 106/1-6

29 Ionaşcu, Zirra, Berciu 1954, 154, fig. 9; Bucureştii de odinioară 1959, 178, pl. LVIII/3. Piesa o cunoaştem doar din reproducerea fotograficà

${ }^{30}$ Panait 1968,73 , fig. $13 / 8$
} 
La Oraşul de Floci (Giurgeni, jud. Ialomița) a fost descoperită o cahlă traforată $(15,7 \times 14 \mathrm{~cm}$, g. placă: $1,2 \mathrm{~cm}$ ) nesmălţuită, decorată în partea stângă a registrului superior cu un merlon în trepte. În registrul inferior, traforul este format dintr-o cruce circumscrisă şi două ferestre suprapuse ${ }^{31}$ (PI. II/4; VII/4). În aceeaşi localitate au fost descoperite şi alte fragmente cu acest decor, dar merlonul este plasat în partea dreaptă (PI. II/3). La montarea piesclor se urmărea, probabil, întâlnirea, în colł̧urile sobci, a merloanelor de la cele două variante omamentale, pentru a crea imaginea unui tum de cetate. Alăturarea, ca elemente de decor, a merlonului, simbol al apărării, cu crucea circumscrisă, simbolul credinţei creştine, dă compoziţiei de pe această teracotă o expresie artistică ingenioasă, o sinteză asupra mentalităţii, crezului şi aspiraţiilor unei populaţii ortodoxe ce vieţuia în vecinătatea şi sub pericolul Islamului. Piesele pot fi încadrate cronologic între sfârşitul secolului al XV-lea şi primele decenii ale secolului al XVI-lea.

De la Vadul Anei (jud. Ilfov) provin câteva fragmente de cahle de coronament (h: 10,5 cm) ornate pe latura superioară cu trapeze traforate, amintind ornamentul cu merloane; registrul inferior, plin, este decorat cu nervuri diagonale, dispuse în spic (PI. II/6; VII/5). Piesele, smălţuite în verde, au înfrumuseţat soba unei locuinţe înstărite, din mediul rural, în secolul al XVI-lea ${ }^{32}$.

La Câmpulung Muscel a fost descoperit un fragment de cahlă $(7,5 \times 7 \mathrm{~cm}, \mathrm{~g}$. placă: $0,8 \mathrm{~cm})$ nesmălţuit, cu registrul superior traforat în forma unor trapeze sau triunghiuri (?); registrul inferior, plin, este decorat în relief, cu motivul ,mure”, mici triunghiuri şi o torsadă ${ }^{33}$. Piesa este databilă în secolul al XVI-lea (Pl. II/5).

Fragmente de cahle de coronament traforate, decorate pe latura superioară cu merloane, au fost descoperite şi la Mânăstirea Tutana ${ }^{34}$. Pe unul dintre fragmente $(8 \times 10 \mathrm{~cm})$, nesmălţuit, sunt redate două merloane ornate, într-un relief plat, cu fleuroni (PI. VIII/1), iar pe alte fragmente $(5 \times 15 \mathrm{~cm} ; 5 \times$ $13 \mathrm{~cm}$ ), smălţuite, culoare verde, decorul laturii superioare este compus din merloane, în ,coadă de rândunică" şi fleuroni stilizaţi (Pl. VII/7-8). Picsele se datează în secolul al XVI-lea. Prin formă şi decor, teracotele traforate formează un coronament cu aspect dantelat.

Pentru analogii tipologice ale formei constructive şi ale decorului, menţionăm cahlele descoperite la Racoşul de Jos, jud. Braşov, databile în prima jumătate a secolului al XVI-lea ${ }^{35}$. Latura superioară a acestora redă o suită de crenele şi merloane, iar traforul, din registrul secund, este format din triunghiuri, încadrate de torsade.

\section{III.A.b. DECOR ANTROPOMORF STILIZAT}

Piesele cu acest ornament au partea superioară decupată în forma unor personaje, foarte mult stilizate, care schiţcază o scenă de dans, ținându-se de mâini (horă). Menţionăm piesele descoperite în ruinele locuinţelor de târgoveţi, de la Oraşul de Floci, şi piesa descoperită la Curtea Domnească de la Târgovişte. La Oraşul de Floci, cahla $(13,2 \times 18 \mathrm{~cm})$, nesmălţuită, are în registrul inferior un decor geometric format din nervuri ce se întretaie, formând romburi ${ }^{36}$ (PI. IIL/1; VII/3). Piesa descoperită la Curtea Domnească din Târgovişte $(14 \times 22 \mathrm{~cm})$, glazurată verde-oliv, este omată în registrul inferior cu o suită de pastile, cu mici protuberanțe ${ }^{37}$ (PI. III/2). Glazura, prezentă la teracotele târgoviştene, ne indică comanditari pretenţioşi, cu posibilităţi financiarc mai mari.

\section{III.A.c. DECOR GEOMETRIC/VEGETAL STILIZAT}

Cahlele traforate pentru coronament au, uneori, latura superioară decorată cu motive geometrice sau vegetale. În Bucureşti, pe str. Covaci, cercetarea ruinelor unei locuinţe medievale din secolul al XVI-lea a scos la lumină un interesant lot de cahle ${ }^{38}$. O piesă de coronament, fragmentară

\footnotetext{
${ }^{31}$ Muzeul Național de istorie a României (în continuare MNIR - nr. inv. 163 788); V. Rădulescu, în: Chị̂escu et alii 1981, 135, fig. 9/2; Rădulescu 2010, 151-163, fig. 2 b.

32 Rădulescu 2010, 154, fig. 6/b. Fragmentele recuperate formează o friză lungă de $37 \mathrm{~cm}$.

${ }^{33}$ Muzeul Municipiului Câmpulung Muscel (nr. inv. 1543).

${ }^{34}$ Muzcul Județean Argeș, Pitești (nr. inv. F. 2175; F. 2242-2244); Cristocea 2001, 113-121, fig. la p. 119

${ }^{35}$ Marcu-Istrate 2004, 258, pl. 120

${ }^{36}$ MNIR (nr. inv. 124 049); Chiţescu et alii 1979, 222, fig. 19/1; Păunescu et alii 2007-2008, pl. 10/7

${ }^{37}$ Petricã 2010,77 , fig. 3

38 Muzeul Municipiului București (=MMB); mulţumim arheologului Mircea Negru, coordonatorul cercetării, pentru permisiunea de a publica piesele.
} 
$(8,2 \times 12 \mathrm{~cm})$, smălţuită, culoare verde, are latura superioară modelată cu o suită de mici piramide. În registrul inferior, traforul formează romburi, iar la întâlnirea dintre unghiuri este redată o pastilă motiv „mură ” (Pl. VIII/2). Tot în Bucureşti, pe str. Lipscani, în zona fostului Han Zlătari, în timpul cercetărilor arheologice din anul 2007, au fost descoperite mai multe teracote ce alcătuiseră, în secolul al XVI-lea, o instalaţie de încălzit ${ }^{39}$. Unele fragmente $(13,5 \times 22 \mathrm{~cm} ; 11 \times 8 \mathrm{~cm} ; 11,6 \times 7,2 \mathrm{~cm})$, nesmălţuite, aparţin tipului cahlelor pentru coronament, traforate, cu latura superioară în formă de flori şi boboci stilizaţi. Traforul geometric din registrul inferior este compus din romburi şi triunghiuri (PI. III/4; VII/6).

La Curtea Domnească din Târgovişte a fost descoperit un fragment de teracotă $(10 \times 7 \mathrm{~cm})$, smălţuit, culoare verde crud, care are forma unei frunze cu marginile crestate. Peţiolul bifurcat creează un trafor. Piesa se datează la sfârşitul secolului al XVI-lea şi decora, probabil, una dintre sobele palatului lui Petru Cercel ${ }^{40}$ (PI. III/6).

\section{III.A.d. DECOR ,FLEURON”}

Un alt decor folosit la cahlele traforate de coronament este fleuronul. Ornamentul a fost inspirat de arhitectura gotică. În secolul al XVI-lea, în spaţiul central european, este realizată soba de la Cracovia, din Castelul Wawel, datând dintre anii $1505-1518^{41}$, sau cea din anul 1570, cu cahle smălţuite policrom, confecţionate probabil pe malul Rinului, împodobind apoi, la Viena, Castelul Mariei Tereza ${ }^{42}$, instalaţii de încălzit care au coronamentul ornat cu fleuroni stilizał̧i.

Pe teritoriul Munteniei, motivul decorativ, mai mult sau mai puţin stilizat, uneori interpretat, este semnalat în secolele XVI-XVII la sobele din Târgovişte, Bucureşti şi Oraşul de Floci. Unele piese, riguros finisate, sunt decupate cu grijă, iar altele, neglijent decupate, pierd traforul, păstrându-se doar conturul din partea superioară a piesei (cahle-placă).

De la Târgovişte, din Palatul Domnesc, epoca Petru Cercel, provine un fragment $(15,5 \times 12$ $\mathrm{cm}$ ) executat îngrijit, smălţuit, culoare galbenă ${ }^{43}$ (PI. III/7; VIIU/4), şi un altul $(9,5 \times 7 \mathrm{~cm})$ smălţuit, culoare verde ${ }^{44}$ (PI. III/5). Piese nesmălţuite, cu acest decor, erau folosite şi la sobele orăşenilor din Târgovişte (PI. III/8). În Bucureşti, cercetările arheologice efectuate în anul 1953, în sectorul Curtea Veche $^{45}$ și în zona Mânăstirii Mihai Vodă, au sesizat fragmente de cahle „,cu ornamente inspirate de arta gotică,46. Fragmentele sunt piese de coronament, traforate, decorate cu fleuroni, datarea lor încadrându-se între sfârş̧itul secolului al XVI-lea şi primele decenii ale secolului următor. Cercetările din anul 2010, de pe str. Lipscani, nr. 32-34, au recuperat, printre alte tipuri de teracote, databile la sfârşitul secolului al XVI-lea, şi piese de coronament $(\mathrm{h}: 16 \mathrm{~cm})$, smălţuite, culoare verde, decorate cu fleuroni stilizaţi ${ }^{47}$ (PI. III/9). Decorul, ca şi dimensiunile (h: $16 \mathrm{~cm}$ ), aceleaşi la cahlele de la București şi la cele de la Târgovişte, evidenţiază existenţa la sfârş̧itul secolului al XVI-lea şi la începutul celui următor a unei mode în ornamentarea instalaţiilor de încălzit, modă pătrunsă în societatea urbană românească sub influenţa culturii central europene.

Piese cu acest model se întâlnesc şi în Transilvania, la Cluj ${ }^{48}$.

\section{III.B. CAHLE-TRAFORATE CU CORP DE FIXARE DE TIP NIŞĂ (UN SFERT DE CILINDRU)}

Acest tip de cahle traforate primesc un corp de fixare (nişă) de forma unui sfert de cilindru, obţinut prin secţionarea, pe înălţime, a unui vas cilindric, lucrat la roata olarului. Corpul de fixare se ataşează pe revers, direct de placa traforată, doar în partea superioară a acesteia, sub ornamentul

\footnotetext{
${ }^{39}$ MMB; mulţumim arheologului Gheorghe Mănucu-Adameşteanu, coordonatorul cercetării, pentru permisiunea de a publica piesele.

${ }^{40}$ Colecţia arhitect C. Ionescu, Târgovişte (nr. inv. 01088)

${ }^{41}$ Franz 1969, fig. 19

${ }^{42}$ Franz 1969, il. 260

43 Slătineanu 1938, Pl. IX/d (imagine publicată răstumat) - Colecţia Institutului de Arheologie „Vasile Pârvan”, Bucureşti

${ }^{44}$ Colecția arhitect C. Ionescu, Târgovişte (nr. inv. 0754)

${ }^{45}$ Lăzărescu-Ionescu et alii 1954, 216, fig. 24/7

${ }^{46}$ Cantacuzino 1959,104 , pl. LXXXIX/2-6 (5, 6 - imagini publicate răsturnat)

${ }^{47} \mathrm{MMB}$; Rădulescu 2011, 117, 122, fig. 1/2, 2/3

${ }^{48}$ Marcu-Istrate 2004, pl. $37 / 80$
} 
supraînălţat al plăcii, pe care îl lasă liber. În partea inferioară, şi pe laterale, între cahla traforată şi corpul de fixare (nişă), spaţiul este obturat de plăcuţe ceramice în forma unor segmente de cerc.

În tările central europene, incă din secolul al XIV-lea, este folosit un procedeu asemănător la confecţionarea nişelor semiconice, ataşate cahlelor traforate pentru coronament. Nişa se obţine prin seç̧ionarea, pe înălţime, a unui vas de formă conică lucrat la roata olarului. Placa traforată, cu aspect dantelat, executată în tipar și apoi decupată, înscrie ornamente geometrice, vegetal-stilizate, figurative sau inspirate din arhitectură, iar uneori chiar mici figurine lucrate separat ${ }^{49}$. Cahlele cu nişă semiconică sunt folosite doar pentru decorarea coronamentului sobelor, pe când cahlele traforate cu nişă semicilindrică pot fi amplasate în registrul volumetric al camerei de încălzire ${ }^{50}$. La sobele din palatul regal de la Vişegrad (Ungaria), datate $1372-1383^{51}$, la Basel ${ }^{52}$ (Elveția) sau la soba de la Tannenberg in Hessen (Germania), distrusă la $1399^{53}$, iar în secolul al XV-lea la Hamburg ${ }^{54}$ (Germania), piesele se încadrează mai multor subtipuri, în funcţie de decor. O astfel de sobă construită la 1473 a existat la Erfurt $^{55}$. Meşterii de cahle din Muntenia interpretează teracotele sobelor central europene şi creează un subtip, propriu pieselor descoperite în spaţiul geografic românesc. Săpăturile arheologice efectuate pe teritoriul Munteniei şi Olteniei au scos la lumină fragmente, dar şi piese întregi sau întregibile, de cahle traforate pentru coronament, cu corp de fixare de tip nişă ${ }^{56}$.

\section{III.B.a. DECOR INSPIRAT DIN ARHITECTURÄ}

Cahlele-traforate pentru coronament, din această categorie tipologică, cu decor inspirat din arhitectură, au fost descoperite la Mânăstirea Buda (jud. Buzău), la Mânăstirea Cătălui-Căscioarele (jud. Giurgiu), la Târgşoru Vechi şi la Oraşul de Floci. Menţionăm că, pentru o parte dintre aceste teracote, corpul de fixare este doar dedus logic, întrucât nu se mai păstrează decât amprenta sa, pe revers. Piesele se încadrează cronologic în secolele XV-XVI.

Motivele decorative inspirate din arhitectura gotică vor fi uneori împrumutate ca atare. Omamentul unor astfel de cahle este format din arcuri de cerc ce se întretaie formând arcade în arc frânt (profilaturi gotice). Câteva fragmente $(\mathrm{h}: 11 \mathrm{~cm}$ ) nesmălţuite au fost descoperitc la Mânăstirea Cătălui-Căscioarele ${ }^{57}\left(\mathbf{P I}\right.$. IV/3) şi la Târgoviște $(11 \times 14 \mathrm{~cm})$, loc nedeterminat ${ }^{58}$ (PI. IV /4). Corpul de fixare nu se păstrează, dar bănuim că el ar fi putut avea forma unui sfert de cilindru. Piesele sunt databile în secolul al XVI-lea.

În alte cazuri, în ormament se va impune stilul local. Rozasa gotică ${ }^{-59}$ se transformă în morişcă circumscrisă, redată $\dot{a}$ jour, iar ferestrele monumentelor gotice se transformă în ferestre cu arcul în plin cintru. Piesele de la Mânăstirea Cătălui-Căscioarele ${ }^{60}(18 \times 18 \mathrm{~cm})$ şi Târgşoru Vechi ${ }^{61}$, nesmălţuite, au ca decor, în registrul superior, triunghiuri retezate, străbătute de nervuri oblice, motiv decorativ ce sugcrează merloane de cetăţi, iar în registrul inferior, o morişcă, redată à jour, încadrată de câte o turlă de biserică, surmontată de cruce. Corpul de montare (nişa) este ataşat, pe revers, sub merloane, iar acestea sunt scoase din planul vertical şi uşor înclinate spre exterior (PI. IV/5-6; VIII /3). O analogie pentru decorul şi forma constructivă a acestor teracote este întâlnită la fragmente descoperite la Mânăstirea Buda 2 .

\footnotetext{
${ }^{49}$ Franz 1969, 31-37, fig. 13, il. 42-53, 55-58, 60-65, 98, 100, 103

${ }^{50}$ Franz 1969

${ }^{51}$ Franz 1969, il. 42

$\$ 2$ Franz 1969 , il. 46

${ }^{53}$ Franz 1969 , il. 43

${ }^{54}$ Franz 1969,47

${ }^{55}$ Franz 1969, il. 102. Reconstruită, soba se păstrează la Dresda, Museum für Kunsthandwerk.

${ }^{56}$ Folosim acest termen, intrat în literatura de specialitate europeană; în bibliografia românească noţiunea „cahlă-nişă" se referă la piesele concave, semicilindrice.

${ }^{57}$ Cantacuzino, Trohani 1979, 303, fig. 27/5

${ }^{58}$ Colecţia arh. C. Ionescu, Târgoviște (nr. inv. 0567)

${ }^{59}$ Franz 1969, il. 48-51

${ }^{60}$ Cantacuzino, Trohani 1979, fig. 27/4; Trohani, Damian, Sârbu 1995, fig. 12/1, 15/1; Rădulescu 2011, fig. 7 a

${ }^{61}$ Rădulescu 2011 , fig. 7 b, c

${ }^{62}$ Muzeul Național de Artă al României (nr. inv. 1666); cercetări arheologice V. Drăghiceanu în anul 1931; Rădulescu 2010, fig. $7 / d$
} 


\section{III.B.b. DECOR GEOMETRIC/ LINEAR}

De la Mânăstirea Cârnu ${ }^{63}$ provine o piesă nesmălţuită $(10,5 \times 16 \mathrm{~cm})$, a cărei placă ajurată este formată din benzi canclate care se arcuiesc şi se întretaie formând triunghiuri, atât în registrul superior cât şi în cel inferior. Un brâu ornat cu mici pătrăţele împarte decorul în două registre (PI. IV/2). Piesa se încadrează cronologic în secolul al XVI-lea.

\section{III.C. CAHLE-TRAFORATE CU CORP DE FIXARE DE TIP NIŞĂ (SEMICILINDRU)}

Corpul de fixare se obţine prin secţionarea, pe înălţime, a unui cilindru lucrat la roata olarului. Ataşarea acestuia pe reversul plăcii traforate se face pe ambele laturi lungi ale plăcii, urmând ca părţile laterale să fie obturate de plăcuțe de lut semicirculare. De obicei, asemenea piese sunt montate în registrul volumetric al camerei de încălzire. La piesele traforate pentru coronament, corpul de fixare (nişa) se ataşează sub decorul supraînălţat (butoni, torsadă, merloane ş.a.).

\section{III.C.a. DECOR GEOMETRIC/LINEAR}

O piesă de coronament traforată $(20 \times 15 \mathrm{~cm})$, smălfuită, culoare verde, deosebită prin decor, a fost descoperită la Schitul Ostrov (Călimănești, jud. Vâlcea ${ }^{64}$ ). Latura superioară este ornată cu o suită de trei butoni conici (h: $5 \mathrm{~cm}$ ). Traforul formează volute, dispuse simetric faţă de axa longitudinală. Deşi corpul de fixare nu se mai păstrează, amprentele lăsate pe revers definesc forma semicilindrică a acestuia (PI. VIII/5.a.-b.). Piesa poate fi încadrată cronologic la începutul secolului al XVI-lea. Aceeaşi formă a corpului de montare o întâlnim şi la un exemplar $(17,5 \times 21 \mathrm{~cm})$ smălţuit, culoare verde-oliv, descoperit la Târgoviște (pasajul Chindia), în timpul unor săpături arheologice de salvare efectuate în anul $1989^{65}$. Traforul redă triunghiuri, iar latura superioară a piesei este formată de un brâu în torsadă (PI. IV/1). Piesa se încadrează cronologic în secolul al XVI-lea.

\section{CAHLE-PLACĀ, PENTRU CORONAMENT}

Cahlele-placă sunt folosite, atât pentru decorarea coronamentului, cât şi a registrelor volumetrice corespunzând camerei de ardere, camerei de încălzire sau soclului sobelor. Cahlele-placă pentru coronament sunt modelate în tipare speciale, de obicei de lemn, mai rar din ceramică, obţinându-se omamentul în relief. Ele pot avea diverse forme: dreptunghiulare, cu latura superioară festonată în forma unui zid de cetate, triunghiulare, fleuroni etc. Decorul este uneori finisat cu ajutorul unei spatule. Se cunosc exemplare nesmălţuite, acoperite cu şlem de culoare cărămizie, micasate, smălţuite într-o singură culoare sau, mai rar, policrome.

\section{IV.A. CAHLE-PLACĂ CU SISTEM DE FIXARE SIMPLU (LAMELÃ)}

Pentru montarea la sobă, acest tip de teracote sunt prevăzute pe latura inferioară cu o lamelă simplă.

\section{IV.A.a. CAHLE-PLACĂ RECTANGULARE, CU DECOR ÎN FORMA UNUI ZID DE CETATE}

Latura superioară a acestor piese cste fasonată în formă de merloane şi crenele.

Frecvente în sccolele XV-XVI, ele sunt puse în legătură cu existenţa sobelor gotice târzii, al căror decor este inspirat de arhitectura militară defensivă a epocii. Pe plan european, asemenea piese sunt cunoscute în Cehia ${ }^{66}$, Tirol ${ }^{67}$ şi Germania ${ }^{68}$. Pe teritoriul românesc, soba monumentală din epoca ştefaniană descoperită la Suceava, în ruinele Casei Domniei, avea coronamentul decorat cu turnuleţe şi

\footnotetext{
${ }^{63}$ Marcu, Lupu 1994, 234, fig. 15 a-d

${ }^{64}$ Muzeul Județcan Vâlcea (nr. inv. 82F)

${ }^{65}$ Complexul Național Muzeal Curtea Domnească „Târgovişte”; informaţii T. Muscã căruia îi mulu̧umim şi pe această cale.

${ }^{66}$ Franz 1969, il. 89, 90; Richterová 1982, tab. 62/3, 63/2, 64/1-6, 65/2, 3

${ }^{67}$ Franz 1969 , il. 104

${ }^{68}$ Franz 1969 , il. $152,153,163$
} 
plăci crenelate ${ }^{69}$. Piese similare au mai fost descoperite şi în alte zone ale oraşului Suceava ${ }^{70}$, precum şi la Vasluii ${ }^{71}$ (jud. Vaslui), Putna ${ }^{72}$, Părhăuţi ${ }^{73}$ (jud. Suceava), Baia ${ }^{74}$. Pentru Transilvania, amintim descoperirile de la Cecheşti ${ }^{75}$ şi Cristurul Secuiesc ${ }^{76}$ (jud. Harghita).

În spaţiul geografic sud-carpatic, o primă încercare de a reda asemenea ornamente o găsim la soba descoperită în ruinele unei locuinţe medievale de la Râmnicu Vâlcea, locuinţă databilă între sfârşitul secolului al XIV-lea şi primele decenii ale secolului al XV-lea. Coronamentul a fost realizat la finalul construcţiei sobei, din lutul folosit ca liant la montarea cahlelor-oală şi a cahlelor-pahar ${ }^{77}$. Ornamentul coronamentului este conceput prin modelarea unor bare de lut, cvasidreptunghiulare, având în partea superioară, la distanţe de 14 centimetri, câte o prelungire paralelipipedică, asemănătoare unor mici merloane (PI. V/1; IX/1). Din punct de vedere al execuţiei tehnice, însă, aceste ornamente nu pot fi considerate cahle.

În Bucureşti, în sectorul Mânăstirii Radu Vodă, a fost descoperită o cahlă-placă de coronament $(15 \times 21,5 \mathrm{~cm})$, cu latura superioară fasonată în formă de merloane în trepte. Registrul inferior, realizat cu ajutorul unei spatule, printr-o tăietură diamantină a lutului, în casete (bosaje de tip diamantin), sugerează zidul de piatră al unei cetăţi. Piesa este nesmălţuită, acoperită cu şlem cărămiziu deschis ${ }^{78}$ (PI. V/6; IX/2). Tot în București, cercetarea arheologică efectuată în anul 2004 pe Calea Victoriei nr. 9-12, aproape de râul Dâmboviţa ${ }^{79}$, a scos la lumină, în zona fundaţiilor unor edificiii de cult din secolul al XVI-lea, fragmente de cahle de coronament, nesmălţuite $(11,6 \times 11 \mathrm{~cm} ; 16 \times 8,4 \mathrm{~cm})$, ornate pe latura superioară cu merloane cu streaşină; pe fiecare merlon este redată câte o cruce patriarhală. În registrul inferior, o compoziţie cu două personaje, una pedestră, iar cealaltă ecvestră, pare să sugereze o scenă de pelerinaj ${ }^{80}$ (Pl. V/5). Deşi redarea grafică este naivă, iconografia, unică pe teracotele cunoscute până acum, trezeşte interes. De la Mânăstirea Cârnu (jud. Buzău), provine o cahlă-placă de coronament $(16 \times 21,6 \mathrm{~cm})$, nesmălţuită, cu latura superioară crenelată, databilă în secolul al XVIlea ${ }^{81}$. Merlonul central, în trepte, este decorat cu o cruce latină, iar registrul inferior cu o suită de trei cruci circumscrise. Registrele sunt despărţite de un brâu în torsadă (PI. V/2). Piesa prezintă putemice urme de ardere secundară.

La Oraşul de Floci, importantă aşezare urbană medievală, cahlele cu latura superioară crenelată, sugerând un zid de cetate, cunosc în registrul inferior variate motive decorative ${ }^{82}$. Una dintre piese $(13 \times 16 \mathrm{~cm})$, nesmălţuită, are cele trei merloane decupate în trepte şi ornate la bază cu motivul pânza de păianjen. În registrul inferior este redată o suită de trei cruci circumscrise, crucea de Malta ${ }^{83}$ $($ Pl. V/3). O altă teracotă descoperită la Oraşul de Floci $(16 \times 20 \mathrm{~cm})$, nesmălţuită, are merloanele prevăzute cu streaşină şi ornate cu steluţe circumscrise. În registrul inferior sunt redate, alăturate, două morişti. Decorul creează compoziţiei senzaţia de mişcare, de vibraţie ${ }^{84}$ (PI. V/4; IX/3).

Un fragment de cahlă-placă, pentru coronament, din secolul al XVI-lea, a fost descoperit şi în cetatea Tabla Buţii ${ }^{85}$.

\footnotetext{
${ }^{69}$ Popa, Mărgineanu-Cârstoiu 1979, 90-91, fig. 76, 90-93

${ }^{70}$ Batariuc 1997, 130-132, 135-136, fig. 5/2-4, fig. $7 / 1-10$, fig. $8 / 1-4,6$, fig. $9 / 2$

${ }^{71}$ Batariuc 1997, fig. 9/1, 5, fig. 10/4

${ }_{73}^{72}$ Batariuc 1997, fig. 8/5

${ }^{73}$ Batariuc 1997, fig. 5/1

${ }_{75}^{74}$ Batariuc 1997, fig. 5/5

${ }^{75}$ Benkö, Ughy 1984 , fig. 16

${ }^{76}$ Marcu-Istrate 2004, pl. 39 B/4

${ }^{77}$ Busuioc 1979, 26; Busuioc, Mărgineanu-Cârstoiu 1979, 279, fig. 10, 11

${ }^{78}$ MNIR (nr. inv. 17 555); Slătineanu 1958, fig. 71; Bucureştii de odinioară 1959, pl. LIX/2; Rădulescu 2010, fig. 2b

${ }^{79}$ Cercetările arheologice au fost efectuate, în anul 2004, de către MMB, coordonator ştiinţific - arheolog dr. Ghe. MănucuAdameşteanu

${ }^{80}$ MMB; Rădulescu 2010, 151-152, fig. 3

${ }_{81}$ Muzeul Județean Buzău; Marcu, Lupu 1994, 234-235, fig. 16/a, b; Rădulescu 2010, 153, fig. 4/a

${ }^{82}$ Chițescu et alii 1979,222 , fig. 14/1-4, 19/2

${ }^{83}$ MNIR (nr. inv. 124 050); Rădulescu 2010, fig. 4 b

${ }^{84}$ MNIR (nr. inv. 124 048); Rădulescu 2010, fig. 5 a

${ }^{85}$ Piesă inedită, in colecţia Muzeului Județean de Istorie şi Arheologie Prahova, Ploieşti
} 


\section{IV.A.b. CAHLE-PLACÃ TRIUNGHIULARE CU DECOR GEOMETRIC/FLORAL}

Pentru decorarea coronamentului sobelor se foloseau şi plăcile de formă triunghiulară. Fragmente ceramice $(14,5 \times 9 \mathrm{~cm})$, cu decor vegetal-geometric, provin din cercetările de la Curtea de Argeş, databile în a doua jumătate a secolului al XIV-lea ${ }^{86}(\mathbf{P I}$. VI/2). Un alt fragment $(7,5 \times 6,5 \mathrm{~cm})$, din secolul al XV-lea, cu decor geometric, a fost descoperit în oraşul medieval Târgşor (PI. VI/1; IX/4). O cahlă-placă, de formă triunghiulară, folosită la decorarea coronamentului sobei, încadrată cronologic în secolul al XVI-lea, provine de la Târgovişte ${ }^{87}$. Decorul este format din două căni (gemene) din care ies plante stilizate (pomul vieţii !), ornament ce poate simboliza ideea de cuplu, deci armonia în familie (PI. VI/3).

\section{IV.A.c. CAHLE-PLACĂ CU DECOR „FLEURON”}

Acest motiv decorativ, folosit în secolul al XVI-lea pentru coronamentul sobelor, este întâlnit. atât la cahlele traforate, cât şi la cahlele-placă. Renunţarea la trafor şi fasonarea doar a laturii superioare a pieselor a simplificat procesul tehnologic şi a asigurat, în acelaşi timp, rezistenţa plăcilor. La teracotele descoperite la Târgoviște s-a constatat că ornamentul fleuron folosit pentru cahlele traforate ale sobelor Palatului Domnesc a fost preluat şi realizat într-o manieră primitivă la cahleleplacă, nesmălţuite, ce decorau sobele caselor de târgoveţi. Fasonarea este rudimentară, iar conturul este parţial pierdut. Cercetările arheologice din cartierul Suseni, Târgovişte (L 4, secolul al XVI-lea) au scos la lumină mai multe fragmente de cahle de coronament decorate cu fleuroni, formând o friză lungă de $85 \mathrm{~cm}^{88}$. Unul dintre fragmente $(16 \times 25,5 \mathrm{~cm})$ păstrează pe latura inferioară urme din lutul folosit la montare (PI. VI/5). Piesele sunt databile la sfârşitul secolului al XVI-lea - primele decenii ale secolului următor.

La Oraşul de Floci, în timpul cercetării arheologice, din anul 1979, a ruinelor unei locuinţe medievale din secolele XVI-XVII, au fost descoperite mai multe fragmente de cahle cu acest ornament (h: $18 \mathrm{~cm})$, smălţuite, culoare verde-argintiu ${ }^{89}$ (PI. IX/5). Ele făceau parte din coronamentul unei sobe care avea în structură şi cahle-placă decorate cu călăraşul valah, leul păzind copacul vietii creştine, precum şi cahle-placă cu mijloc circular concav ${ }^{90}$. Tot de la Oraşul de Floci provine şi un fragment ceramic în formă de fleuron $(14,4 \times 8 \mathrm{~cm})$, decorat cu o pasăre în zbor (pescăruş). Piesa este smălţuită, culoare verde oliv; se încadrează cronologic la sfârşitul secolului al XVI-lea (PI. VI/4).

\section{ALTE FORME}

Coronamentul sobelor prezintă, uneori, forma unui tor. $\mathrm{Cu}$ ocazia sondajelor făcute la casele cantacuzine de la Măgureni, jud. Prahova, a fost recuperat un fragment de friză ceramică, cu caracter ornamental, pentru coronamentul sobelor. Piesa, de formă semicirculară în secţiune, este decorată, în relief, cu vrejuri şi palmete. Pe una dintre laturile lungi, cea superioară, apare o suită de pătrate, alternând, unul în prim plan cu următorul retras. Smalţul este de culoare verde, de bună calitate, aplicat peste angobă. Piesa se datează la sfârșitul secolului al XVII-lea ${ }^{91}$.

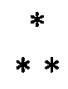

Încadrate în stilul epocii, cahlele medievale pentru coronament descoperite în Valahia înscriu o varietate a formelor constructive, precum şi a ornamentelor. Moda sobelor din ţările central europene a influenţat confecţionarea cahlelor din Tara Românească, dar unele dintre modelele preluate au fost prelucrate şi adaptate specificului local. Se poate constata, din punct de vedere al formelor

\footnotetext{
${ }^{86}$ Bătrâna, Bătrâna $1982,103, \mathrm{pl} . \mathrm{I} / 2$

${ }^{87}$ Slătineanu 1958, fig. 126

${ }^{88}$ Complexul Naţional Muzeal Curtea Domnească „Târgovişte” (nr. inv. 10.702/375). Piesele au fost descoperite în două zone diferite ale oraşului, de către arheologii T. Muscă şi G. Mihăescu, cărora le mulţumim pentru informaţii.

${ }^{89}$ MNIR (nr. inv 163 811-163 818). Descoperiri similare au fost făcute şi în alte zone ale oraşului medieval ialomiţean

${ }^{90}$ Rădulescu, în: Chițescu et alii 1981,135

${ }^{91}$ Slătineanu 1958, 192, fig. 107
} 
constructive, existenţa unor tipologii proprii cahlelor munteneşti. Ca ornamentaţie, în secolele XVXVI se remarcă frecvența motivului zidul de cetate, cu crenele şi merloane, asociat cu crucea, o expresie simbolică a dezideratelor societăţii medievale de pe aceste meleaguri, apărarea teritorială şi a credinţei creştine. În a doua jumătate a secolului al XVI-lea şi în primele decenii ale secolului al XVIIlea, în mediul urban, coronamentul sobelor se orientează spre motivul fleuron. Noi săpături arheologice şi cercetarea amănunţită a coleç̧iilor de stat sau particulare vor completa, desigur, aceste prime observaţii.

\section{BIBLIOGRAFIE}

Batariuc 1997

Bătrâna, Bătrâna 1981

Bătrâna, Bătrâna 1982

Benkö, Ughy 1984

Бирташевиъ 1970

Boldizsár 1988

Busuioc 1979

Busuioc,

Mărgineanu-Cârstoiu 1979

\section{Bucureştii de}

odinioară 1959

Cantacuzino 1959

Cantacuzino,

Trohani 1979

Chițescu et alii 1979

Chiţescu et alii 1981

Constantinescu,

Ionescu 1980

Constantinescu 1984

Cristocea 2001

Diaconescu 1997

Franz 1969

Hoššo 1982

Ionaşcu, Zirra,

Berciu 1954
P. V. Batariuc, Cahle de coronament din Moldova (secolele XIV-XV), Arheologia Moldovei, XX, 1997, p. 127-151

L. Bătrâna, A. Bătrâna, Cercetări arheologice efectuate în anul 1979 în cuprinsul aşezării Curtea de Argeş, jud. Argeş, $C A$, IV, 1981, p. 144-171

L. Bătrâna, A. Bătrâna, Cercetările arheologice de la Curtea de Argeș, $C A, \mathrm{~V}$, 1982, p. $95-107$

E. Benkö, I. Ughy, Székelykeresztútri Kályhacsempék, 15-17. század, Bukarest, 1984

М. Бирташевиъ, Средњовековна керамика, Belgrad, 1970

P. Boldizsár, Gótikus kályhacsempék az újabb budaváry ásatás leletanyagából, A Móra Ferenc Múzeum Évkönyve, Szeged, 1988, 1

El. Busuioc, Vestigii feudale de la Râmnicu Vâlcea, Buridava, 3, 1979, p. 24-29

El. Busuioc, M. Mărgineanu-Cârstoiu, Mittelalterliche Kachelofenarten in den rumänischen Fürstentümern (XIV-XV Jahrhundert), Dacia N.S, XXIII, 1979, p. 275-289

Bucureştii de odinioară în lumina cercetārilor arheologice, Bucureşti, 1959

Ghe. Cantea (Cantacuzino), Cercetările arheologice pe dealul Mihai Vodă și împrejurimi, în Bucureştii de odinioară 1959, p. 93-127

Ghe. Cantacuzino, G. Trohani, Săpăturile arheologice de la Cătălui-Căscioarele, jud. Ilfov, $C A$, III, 1979 , p. 262-328

L. Chiţescu, N. Conovici, R. Lungu, A. Păunescu, V. Rădulescu, Cercetări arheologice la Piua Petrii (Oraşul de Floci), jud. Ialomiţa, CA, III, 1979, p. 199246

L. Chiţescu, R. Lungu, T. Papasima, P. Vlădilă, V. Rădulescu, A. Păunescu, Cercetãri arheologice în anul 1979 la Piua Petrii (Oraşul de Floci), comuna Giurgeni, jud. Ialomiţa, $C A$, IV, 1981, p. 120-143

N. Constantinescu, C. Ionescu, Asupra habitatului urban de la Târgovişte înainte de 1394. Repere din vatra Curţii Domneşti, SCIVA, 31, 1980, nr. 1, p. 53-75

N. Constantinescu, Curtea de Argeş (1200-1400). Asupra inceputurilor Tării Româneşti, Bucureşti, 1984

Sp. Cristocea, Cercetările arheologice şi problema casei domneşti de la Mânăstirea Tutana, jud. Argeș, Argessis. Studii şi comunicări. Seria Istorie, X, Pitești, 2001, p. 113-121

P. Diaconescu, Cercetări arheologice la Curtea Domnească din Târgoviş̧e, Valahica, 15, 1997, p. 53-70

R. Franz, Der Kachelofen. Entstehung und kunstgeschichtliche Entwicklung vom Mittelalter bis zum Ausgang des Klassizismus, Graz, 1969

J. Hoššo, Neskorogotika kachlova pecz Liptovskej Mary, Archaeologija Historica, Kosice, 7, 1982, p. 499-508

I. Ionaşcu, Vl. Zira, D. Berciu, Săpăturile arheologice din sectorul Radu Vodă, Bucureşti, în Rezultatele săpăturilor arheologice şi ale cercetărilor istorice din anul 1953, București, 1954, p. 132-183 
Ionescu 1983

Kálmán 1938

Lăzărescu-Ionescu et alii 1954

Marcu, Lupu 1994

Marcu-Istrate 2004

Moisescu 1979

Neamţu, Neamţu,

Cheptea 1980

Neamţu, Neamţu,

Cheptea 1984

Nicolescu 1961

Nicolescu 1964

Panait 1968

Păunescu

et alii 2007-2008

Petrică 2010

Popa,

Mărgineanu-Cârstoiu 1979

Rădulescu 2010

Rădulescu 2011

Richterová 1982

Rosetti 1935

Scurtă istorie 1957

Slătineanu 1938

Slătineanu 1958

Theodorescu 1976

Trohani, Damian,

Sârbu 1995
C. Ionescu, Consideraţii asupra arhitecturii şi urbanismului oraşului Târgoviște în a doua jumătate a veacului al XIV-lea, Revista muzeelor şi monumentelor. Monumente istorice şi de artă, nr. 2, 1983, p. 65-70

Sz. Kálmán, Az. alfódi magyar nép múvelódés - tórténeti emlékei, Budapest, 1938

L. Lăzărescu-Ionescu, D. V. Rosetti, Gh. Ionescu, Gh. Astangăi, H. Teodoru, Săpăturile arheologice din sectorul Curtea Veche, București, în Rezultatele săpäturilor arheologice şi ale cercetărilor Istorice din anul 1953, București, 1954, p. $184-261$

D. Marcu, Em. Lupu, Cahlele din secolele XVI-XVII aflate în colecţia Muzeului județean Buzău, Mousaios, IV, 1994, p. 234-235

D. Marcu-Istrate, Cahlele din Transilvania și Banat de la începuturi până la 1700, Cluj-Napoca, 2004

Cr. Moisescu, Târgovişte. Monumente istorice şi de artă, Bucureşti, 1979

Eug. Neamţu, V. Neamţu, St. Cheptea, Oraşul medieval Baia in secolele XIVXVII, I, Iași, 1980

Eug. Neamţu, V. Neamţu, St. Cheptea, Oraşul medieval Baia în secolele XIVXVII, II, Iași, 1984

C. Nicolescu, Începuturile ceramicii ornamentale în Moldova, în T. Vianu, M Popescu (ed.), Omagiu lui George Oprescu, București, 1961, p. 373-394

C. Nicolescu, Arta în epoca lui Ştefan cel Mare. Antecedentele şi etapele de dezvoltare ale artei moldoveneşti din epoca lui Ștefan cel Mare, în Cultura moldoveneascá în timpul lui Stefan cel Mare, Bucureşti, 1964, p. 259-362

P. I. Panait, Şantierul Băneasa Străulești. Cercetările din sectorul Măicăneşti (1964-1966). Așezarea feudală, MatIstMuzBuc, VI, 1968, p. 83-93

A. Păunescu, I. Ene, D. Mihai, Ghe. Matei, G. Vasile, Cercetări arheologice în vatra Oraşului de Floci, (Piua Petrii), comuna Giurgeni, judę̧ul Ialomiţa. Campaniile din anii 2006-2007, CA, XIV-XV, 2007-2008, p. 11-26

F. G. Petrică, Three medieval stove tiles from the Princiary Court of Târgovişte, Annales d'Université ,Valahia" Târgoviște. Section d'Archéologie et d'Histoire, Tome XII, Numero 2, 2010, p. 73-78

R. Popa, M. Mărgineanu-Cârstoiu, Mărturii de civilizatie medievală românească. O casă a domniei şi o sobă monumentală de la Suceava din vremea lui Ștefan cel Mare, București, 1979

M. V. Rădulescu, Cahle de coronament din Muntenia decorate cu crenele şi merloane (sec. XV-XVI), în C-tin Razachievici (ed.), Izvoare istorice, artă, cultură și societate. În memoria lui Constantin Bälan (1928-2005), București, 2010, p. 151-163

M. V. Rădulescu, Cahle de la sfârşitul secolului al XVI-lea descoperite în centrul vechi al oraşului București (str. Lipscani, nr. 32-34), în Ghe. MănucuAdameșteanu (ed.), O jumătate de veac în slujba istoriei Bucureştilor. Omagiu profesorului Panait Ion Panait, la 80 de ani Muzeul Municipiului Bucureşti, vol. II, 2011, p. 116-139

J. Richterová, Středověkékachle, Praga, 1982

D. V. Rosetti, Săpăturile arheologice de la Snagov, I, Bucureşti, 1935

Scurtă istorie a artelor plastice în R. P. R., București, 1957

B. Slătineanu, Ceramica românească, Bucureşti, 1938

B. Slătineanu, Ceramica feudală românească, Bucureşti, 1958

R. Theodorescu, Un mileniu de artă la Dunärea de Jos (400-1400), București, 1976

G. Trohani, P. Damian, V. Sârbu, Nouvelles recherches archéologiques à CätăluiCăscioarele, dep. Călăraşi, CCDJ, XIII-XIV, 1995, p. 233-257 
PI. I. 1. Târgovişte, stove of dwelling $1 \mathrm{~B}$, late $14^{\text {th }} \mathrm{c}$. (graphic reconstruction, apud Constantinescu, Ionescu 1980, fig. 6); Canopy disc tiles, late $14^{\text {th }}$ c.- $15^{\text {th }}$ c.: 2-5. Târgovişte; 3-4. Târgşoru Vechi (fragments)

Pl. II. Canopy convex tiles, $14^{\text {th }}-15^{\text {th }}$ c. 1. Snagov Monastery (apud Rosetti 1935, fig. 35); 2. Târgovişte, medieval dwelling; Canopy fretwork tiles, $16^{\text {th }}$ c. 3-4. Oraşul de Floci; 5. Câmpulung Muscel (fragment); 6. Vadul Anei (fragmentary)

PI. III. Canopy fretwork tiles, sec. $15^{\text {th }}$ c.- $16^{\text {th }}$ c.: 1 . Oraşul de Floci (apud Chitescu et alii 1979, fig. 14/1); 2. Târgovişte (apud Petrică 2010, fig. 3); 3. Bucureşti, Măicăneşti sector (apud Panait 1968, fig. 13/8); 4. Bucureşti, Historic Centre; Canopy fretwork tiles, late $16^{\text {th }}$ c. (fragments): 5-7. Târgovişte, Princely Palace; 8. Târgovişte, medieval dwelling; 9. Bucureşti, Historic Centre

PI. IV. Canopy fretwork tiles with niche type fixing frame, $16^{\text {th }} \mathrm{c}$., fragments: 1 . Târgovişte; 2 . Câmu Monastery (apud Marcu, Lupu 1994, fig. 15 a-b); 3, 5. Cătălui-Căscioarele Monastery (apud Cantacuzino, Trohani 1979, fig. 27/5; apud Trohani, Damian, Sârbu 1995); 4. Târgovişte; 6. Târgşoru Vechi

PI. V. Canopy plate tiles, $15^{\text {th }}-16^{\text {th }} \mathrm{c}$. 1 . Stove canopy, Rm. Vâlcea, $14^{\text {th }}-15^{\text {th }}$ c. (graphic reconstruction, apud Busuioc, Mărgineanu-Cârstoiu 1979, fig. 10); 2. Câmu Monastery, $16^{\text {th }}$ c. (apud Marcu, Lupu 1994, fig. 16 a); 3 , 4. Oraşul de Floci, $15^{\text {th }}-16^{\text {th }}$ c. (apud Chiţescu et alii 1979, fig. 14/1, 19/2); 5. București, Historic Centre, $15^{\text {th }}-$ $16^{\text {th }}$ c. (graphic reconstruction); 6. Bucureşti, Radu Vodã Monastery, $15^{\text {th }}-16^{\text {th }}$ c. (apud Slătineanu 1958, fig. 71)

PI. VI. Canopy plate tiles (fragments): 1. Târgşoru Vechi, $15^{\text {th }} \mathrm{c}$.; 2. Curtea de Argeș, $14^{\text {th }}-15^{\text {th }} \mathrm{c}$. (apud Bătrâna, Bătrâna 1982, pl. I/2); 3. Târgovişte, $16^{\text {th }}$ c. (apud Slătineanu 1958, fig. 126); 4. Oraşul de Floci, late $16^{\text {th }} \mathrm{c}$.; 5. Târgovişte, medieval dwelling, $16^{\text {th }}-17^{\text {th }} \mathrm{c}$

PI. VII. 1. Convex tile, Târgovişte, late $14^{\text {th }} \mathrm{c}$.; 2. Disc tile, Târgşoru Vechi, $15^{\text {th }} \mathrm{c}$.; Fretwork tiles, $16^{\text {th }} \mathrm{c}$. 3-4. Oraşul de Floci; 5. Vadul Anei; 6. Bucureşti, Historic Centre; 7-8. Tutana Monastery

PI. VIII. Fretwork tiles, $16^{\text {th }}$ c. 1. Tutana Monastery; 2. Bucureşti, Covaci Street; 3. Cătălui-Căscioarele Monastery; 4. Târgovişte, Princely Palace; 5. Ostrov Hermitage (a. obverse; b. reverse)

PI. IX. 1. Rm. Vâlcea, stove, late $14^{\text {th }}$ c. (graphic reconstruction, apud Busuioc, Mărgineanu-Cârstoiu 1979);

Canopy plate tiles: 2 . Bucureşti, Radu Vodã Monastery, $15^{\text {th }}-16^{\text {th }}$ c.; 3. Oraşul de Floci, $15^{\text {th }}-16^{\text {th }}$ c.; 4. Târgşoru Vechi, $15^{\text {th }} \mathrm{c}$.; 5. Oraşul de Floci, late $16^{\text {th }} \mathrm{c}$.

Desene: Simona Mateescu, Jeni Efimov, Euterpia Petrache

MARIA VENERA RĂDULESCU

Muzeul Naţional de Istorie a României, Calea Victoriei 12, sector 2 ,

Bucureşti 


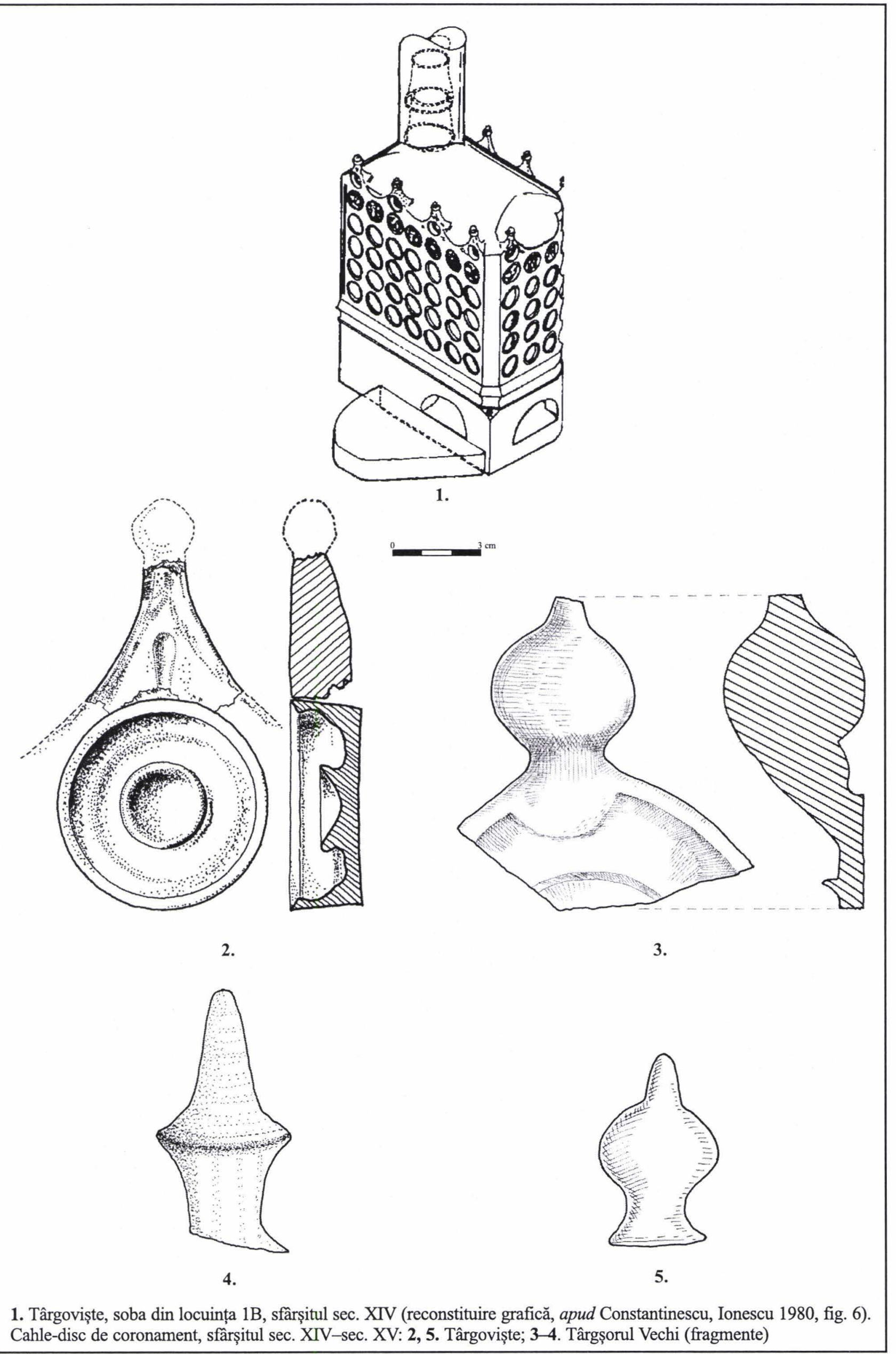

PI. I 


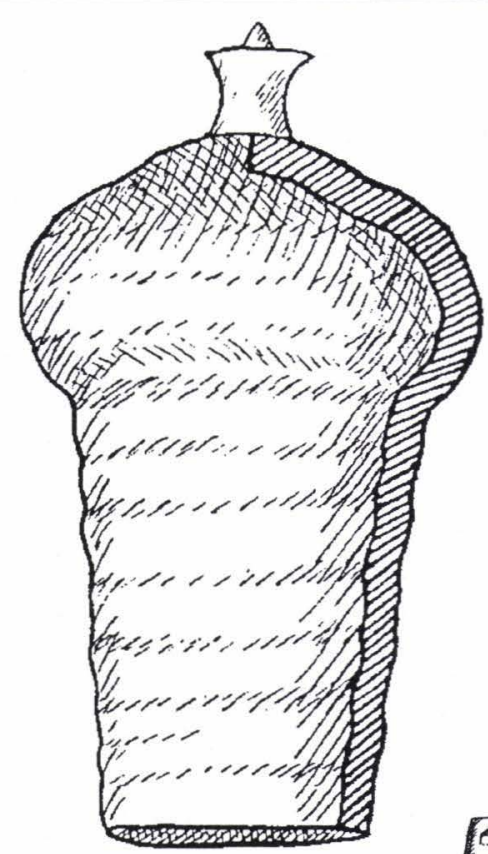

1.

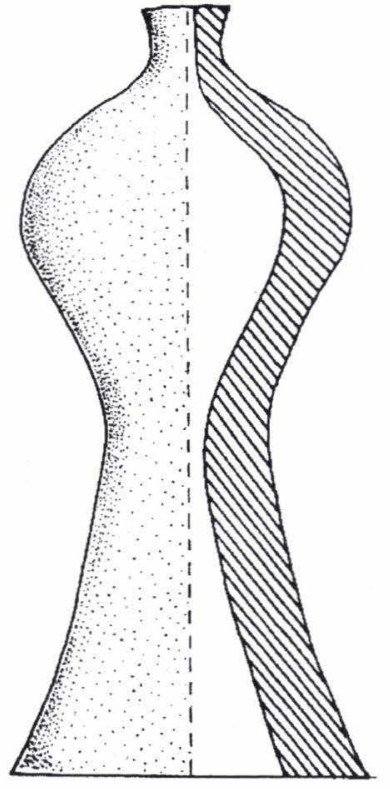

2.

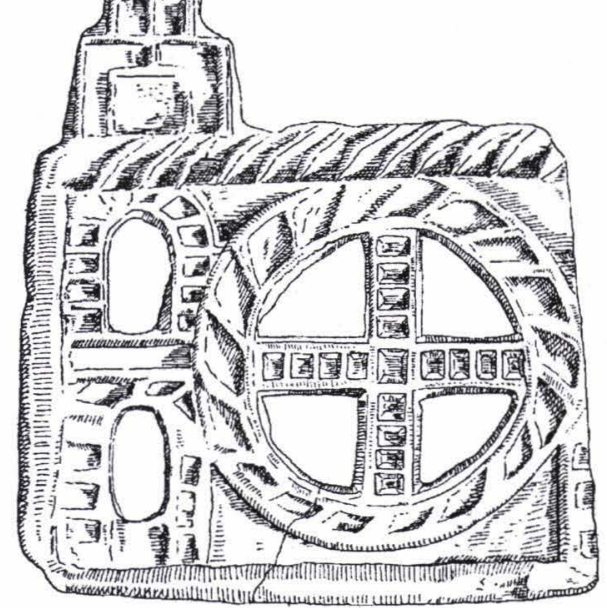

4.

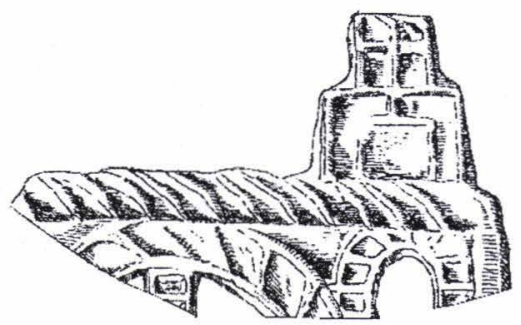

3.

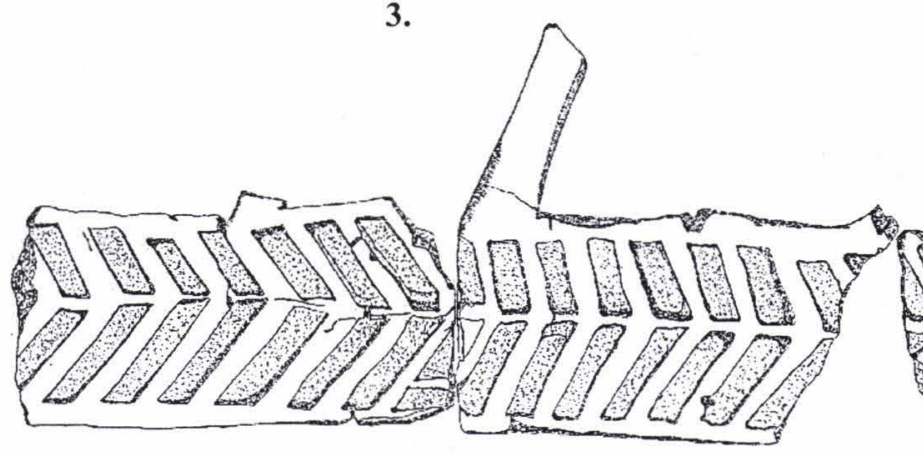

6.

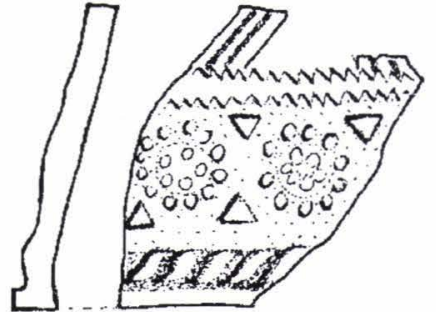

5.

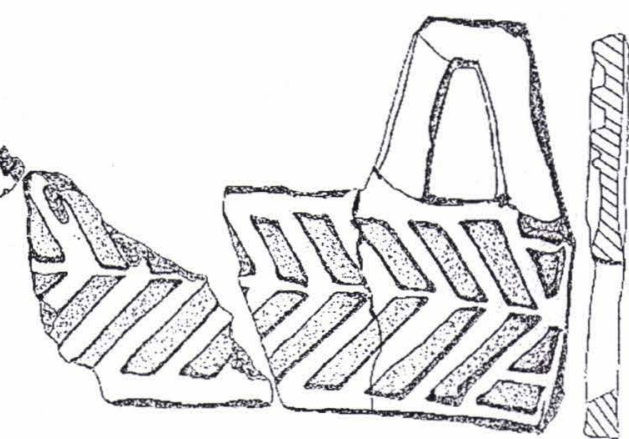

Cahle-convexe de coronament, sec. XIV-XV: 1. Mânăstirea Snagov (apud Rosetti 1935, fig. 35); 2. Târgoviște, locuință medievală. Cahle-traforate de coronament, sec. XV-XVI: 3-4. Orașul de Floci; 5. Câmpulung Muscel (fragment) 6. Vadul Anei (fragmentară). 


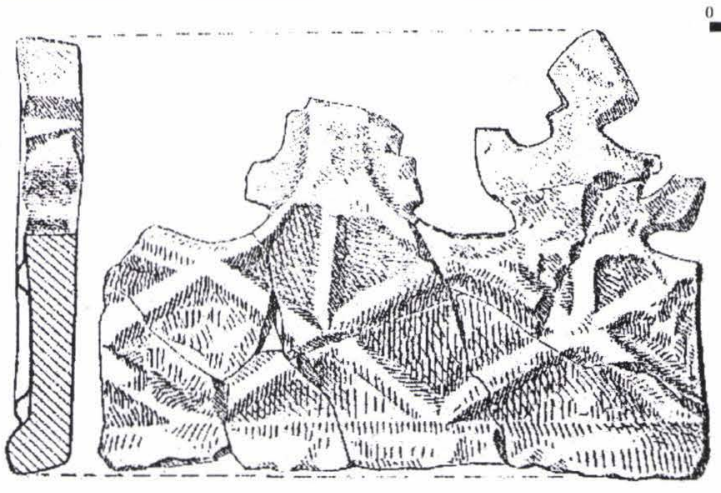

1.
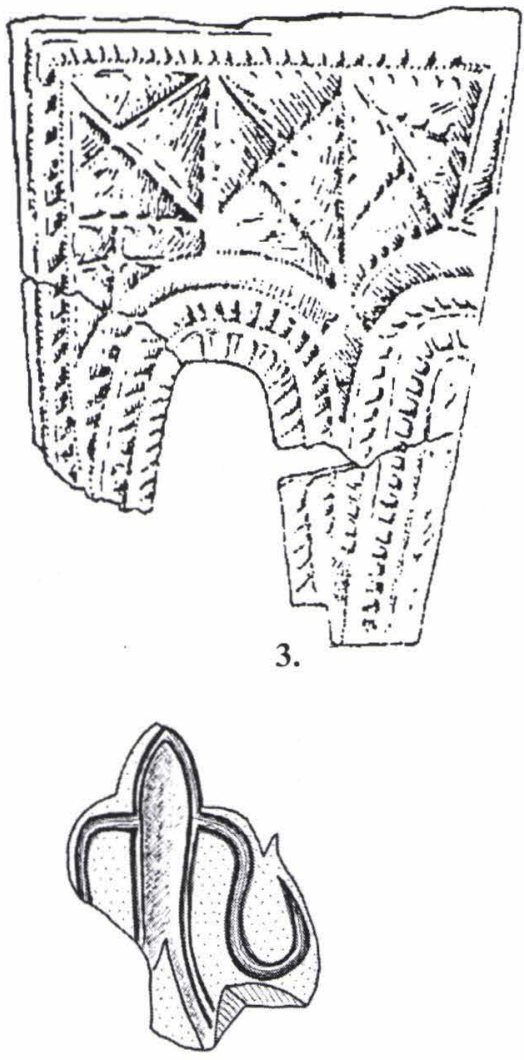

5.

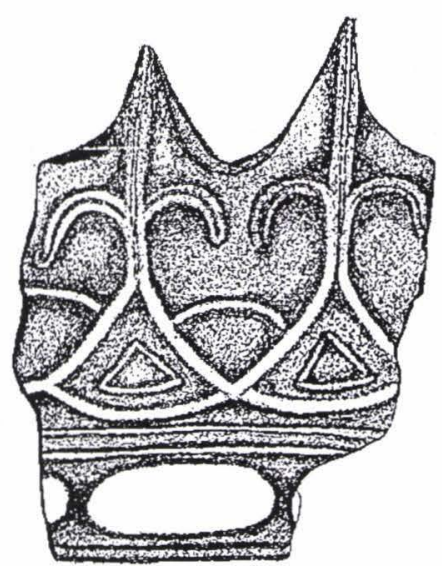

8.

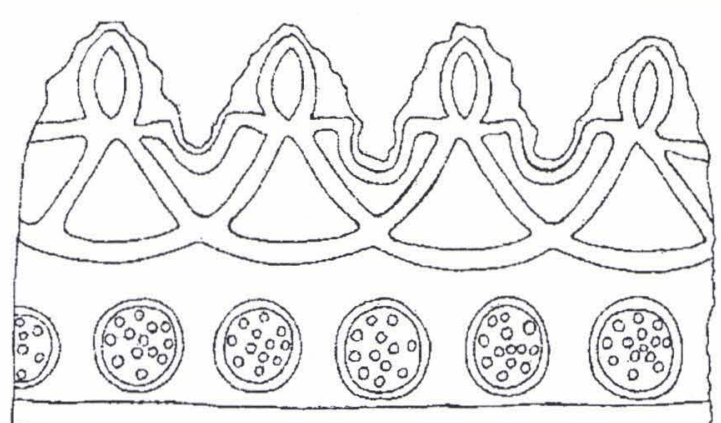

2.
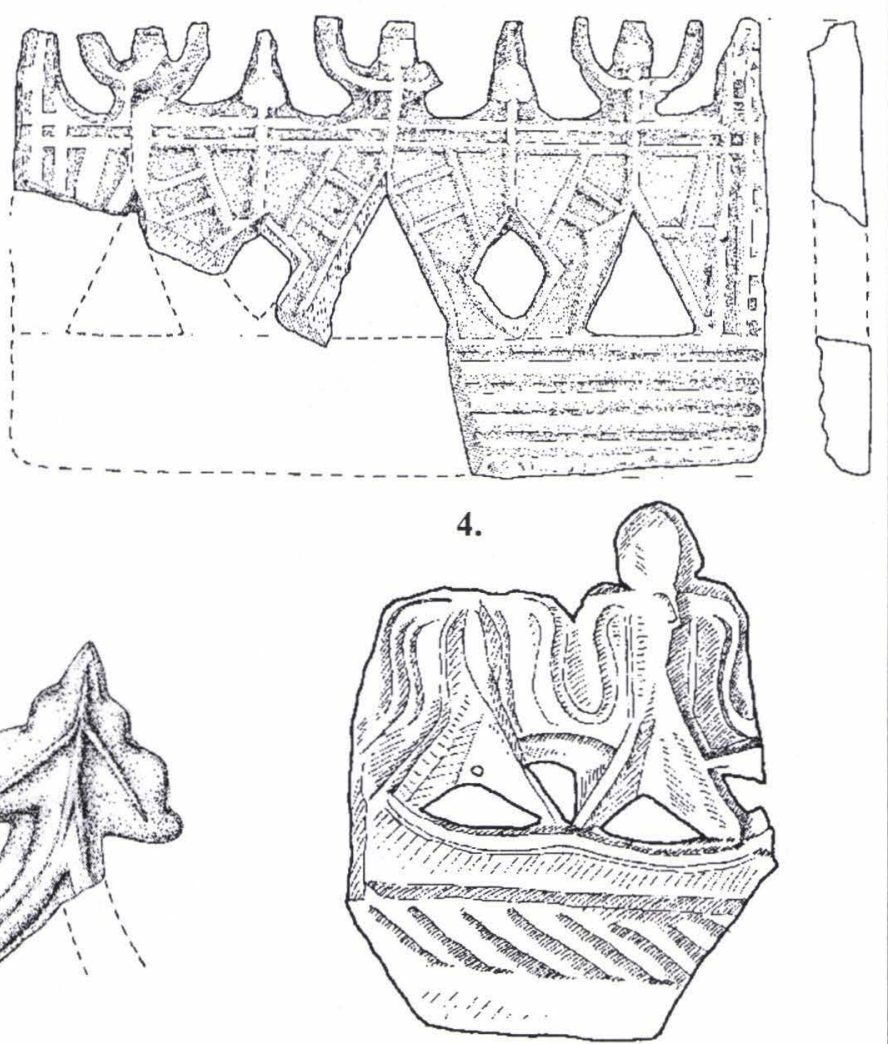

6.

7.

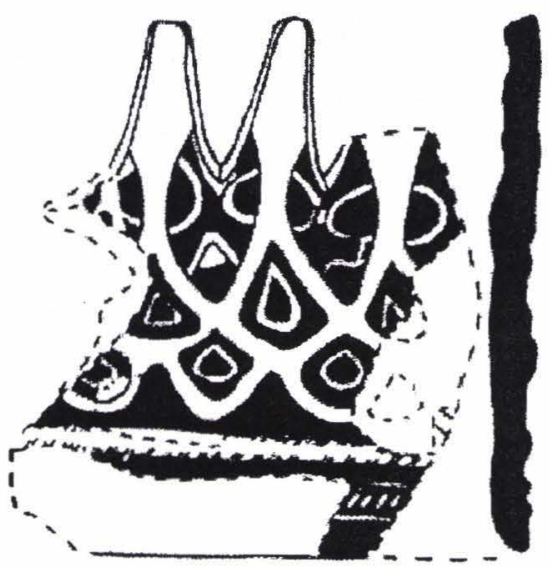

9.

Cahle-traforate de coronament. Sec. XV-XVI: 1. Orașul de Floci (apud Chițescu et alii 1979, fig. 19/1); 2. Târgoviște (apud Petrică 2010, fig. 3); 3. București, sector Măicănești (apud Panait 1968, fig. 13/8); 4. București, Centul istoric. Sfârșitul sec. XVI: 5-7. Târgovişte, Palatul domnesc; 8.Târgoviște, locuință medievală; 9. București, Centrul istoric 


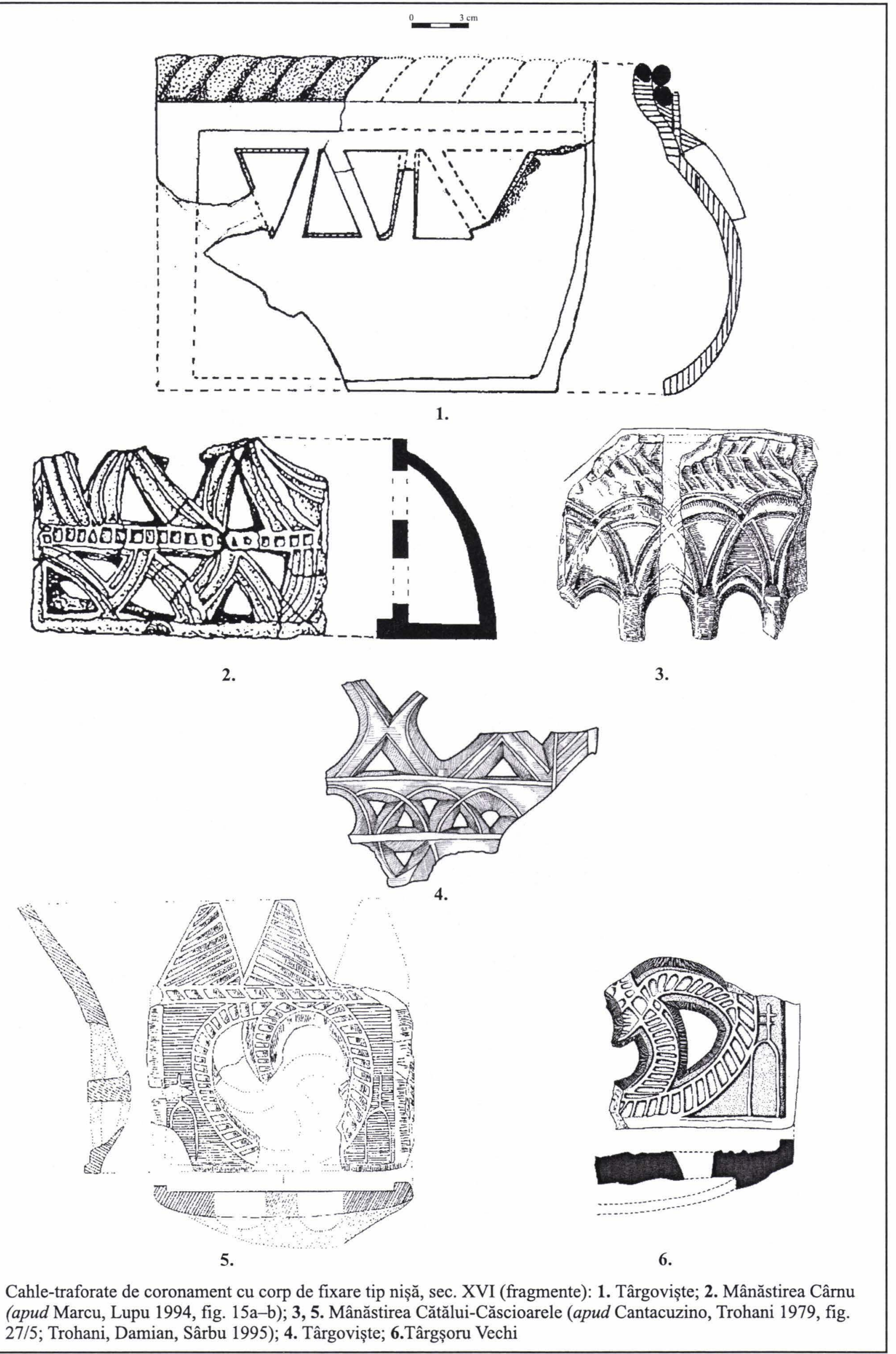




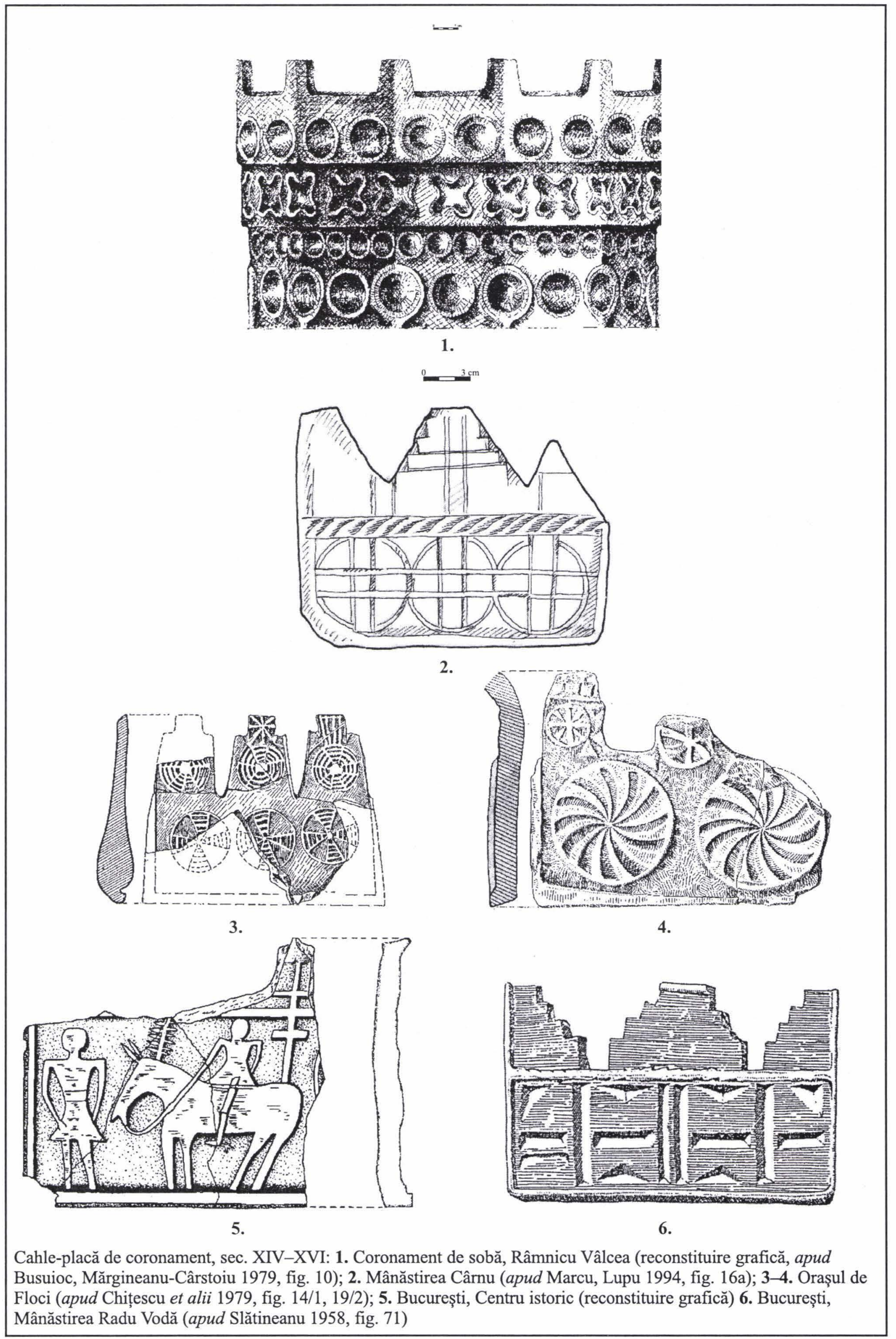




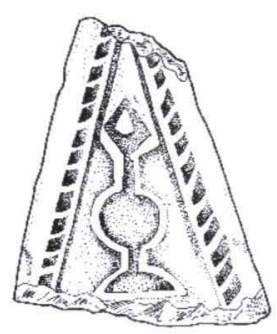

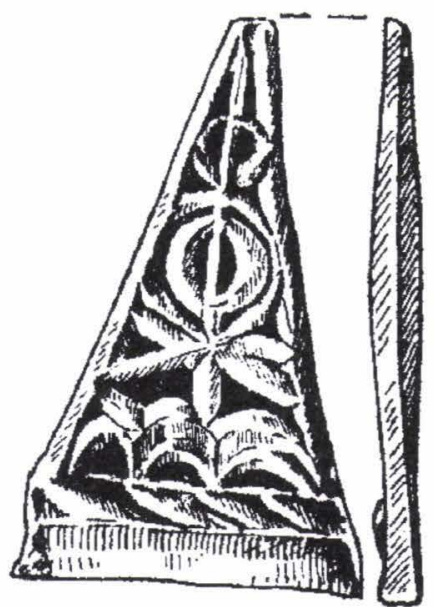

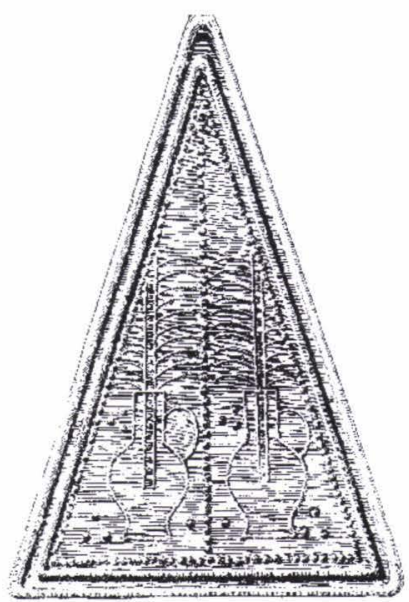

3.
2.

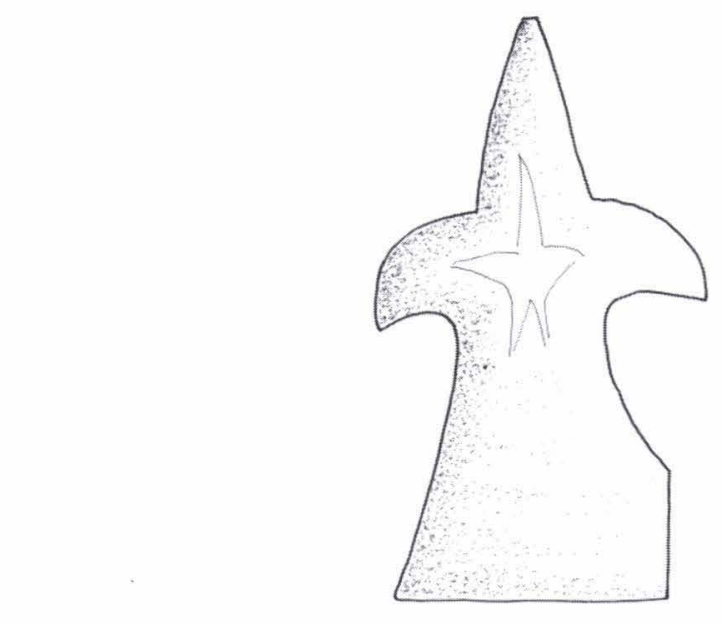

4.

1.

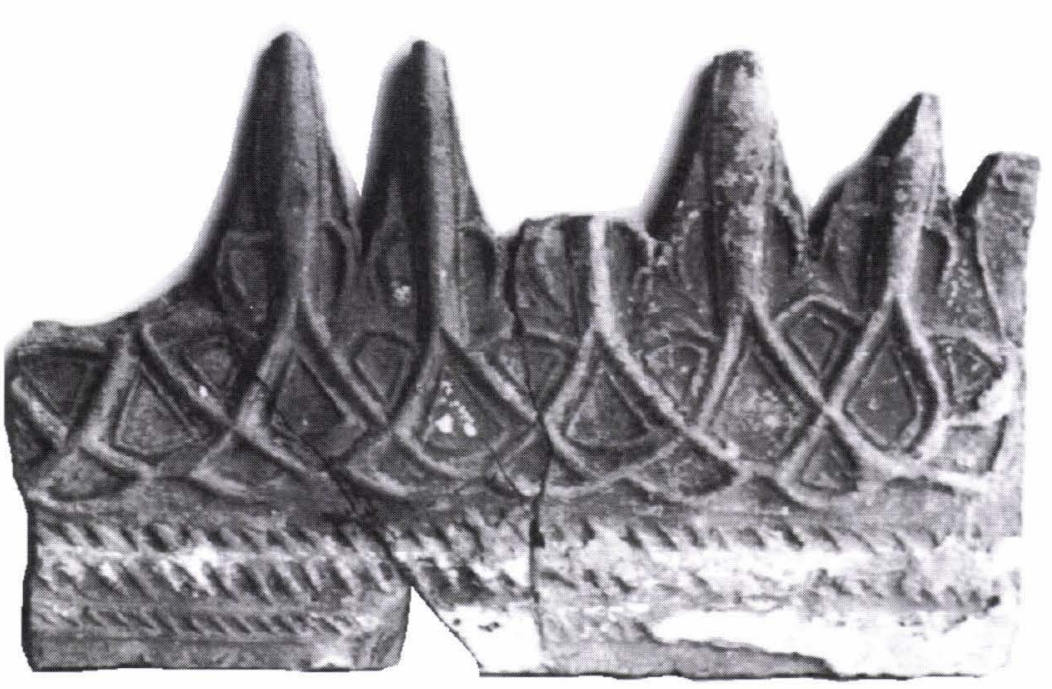

5.

Cahle-placă de coronament (fragmente): 1. Târgușoru Vechi, sec. XV; 2. Curtea de Argeș, sec. XIV-XV (apud Bătrâna Bătrâna 1982, pl. I/2); 3. Târgoviște, sec. XVI (apud Slătineanu 1958, fig. 126); 4. Orașul de Floci, sfârșitul sec. XVI; 5. Târgoviște, locuință medievală, sec. XVI-XVII 


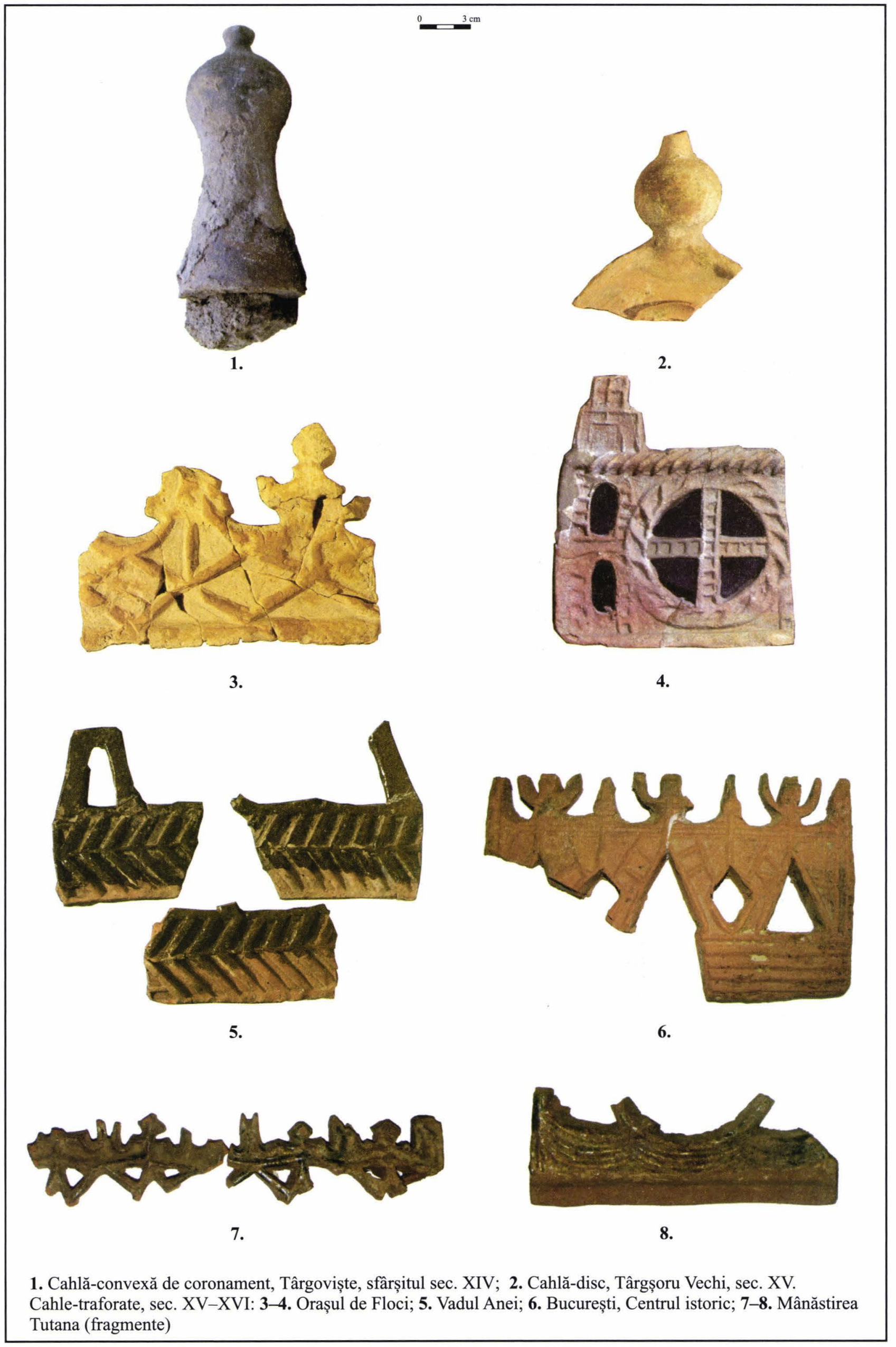




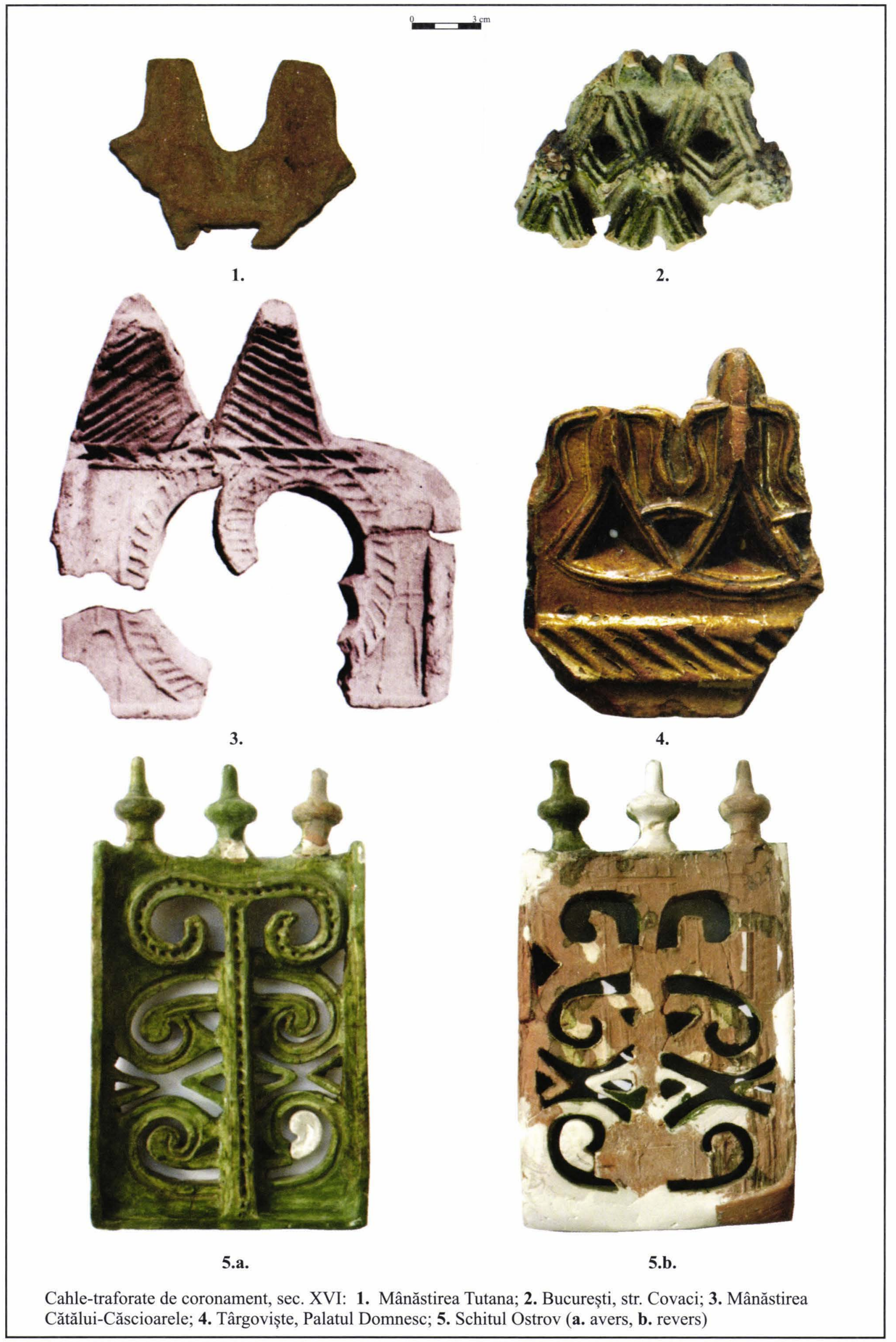




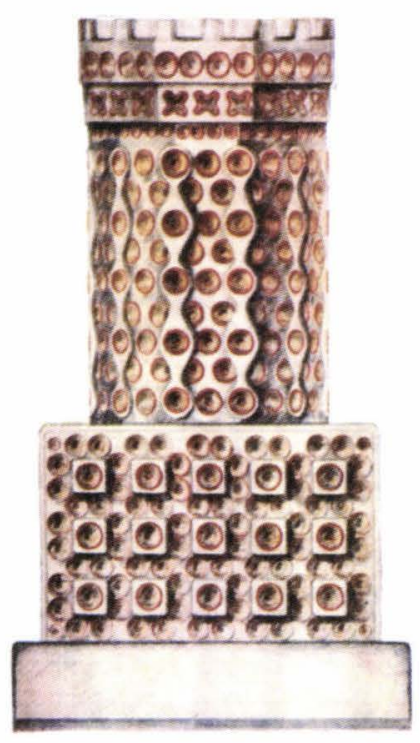

1.

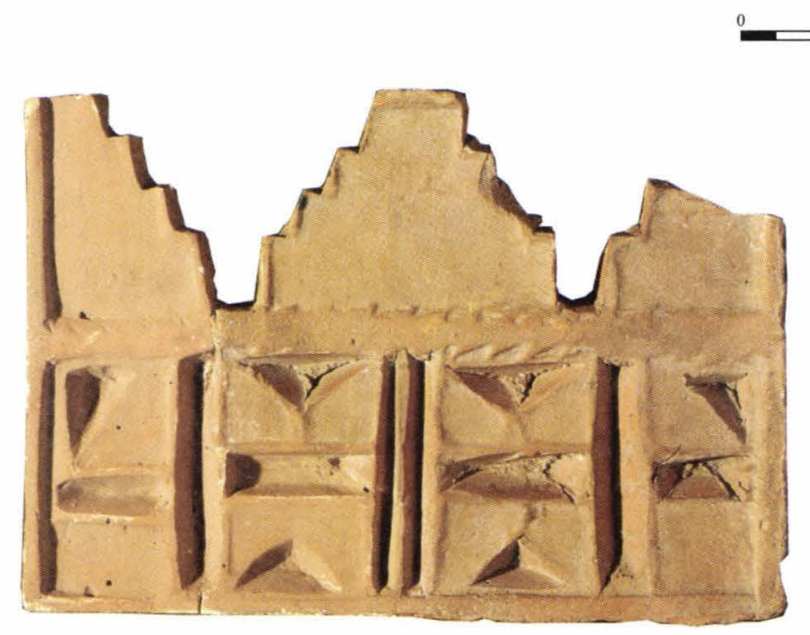

2.

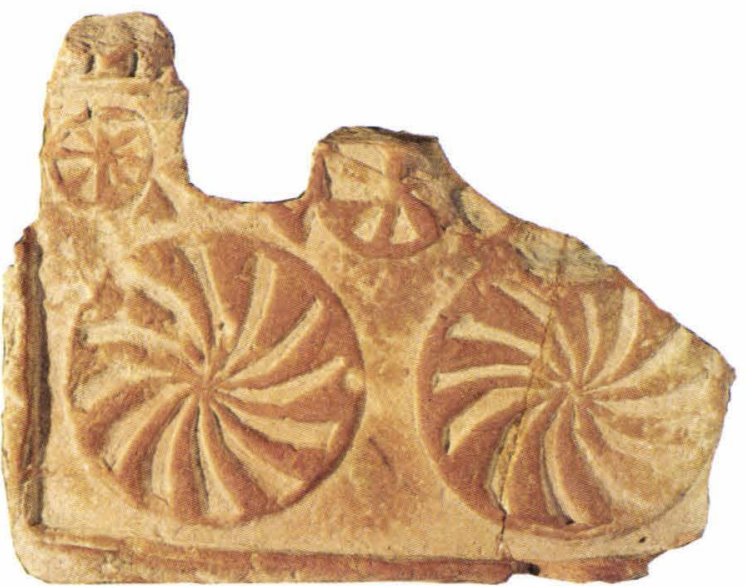

3.
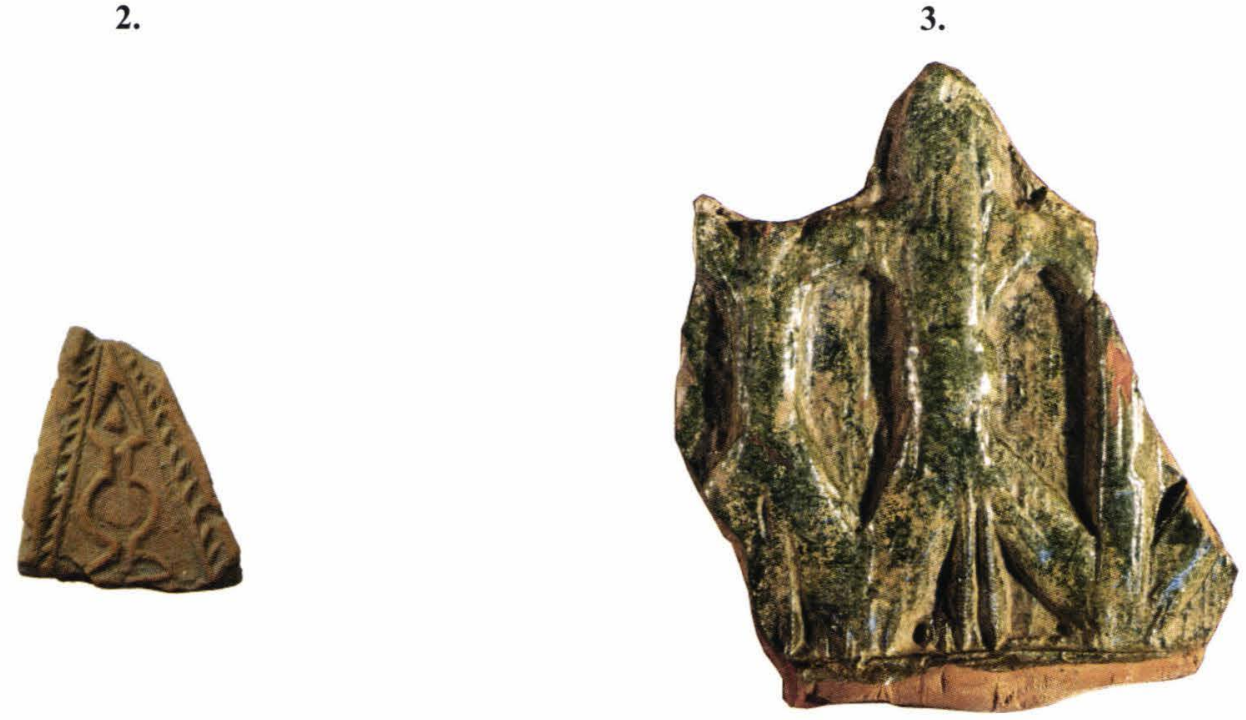

4.

5.

1. Râmnicu Vâlcea, sobă, sfârșitul sec. XIV (reconstituire grafică, apud Busuioc, Mărgineanu-Cârstoiu 1979).

Cahle-placă de coronament: 2. București, Mânăstirea Radu Vodă, sec. XV-XVI; 3. Orașul de Floci, sec. XV-XVI; 4. Târgșoru Vechi, sec. XV; 5. Orașul de Floci, sfârșitul sec. XVI 
